\title{
2-Phenyloxazole-4-carboxamide as a scaffold for selective inhibition of human monoamine oxidase $B$
}

\author{
Maria L. Di Paolo, ${ }^{[b]}$ Michael S. Christodoulou, ${ }^{[c]}$ Alessandra M. Calogero, ${ }^{[d]}$ Luca Pinzi, ${ }^{[e]}$ Giulio \\ Rastelli, ${ }^{[\mathrm{e}]}$ Daniele Passarella, ${ }^{[f]}$ Graziella Cappelletti, ${ }^{[\mathrm{d}]}$ and Lisa Dalla Via*[a]
}

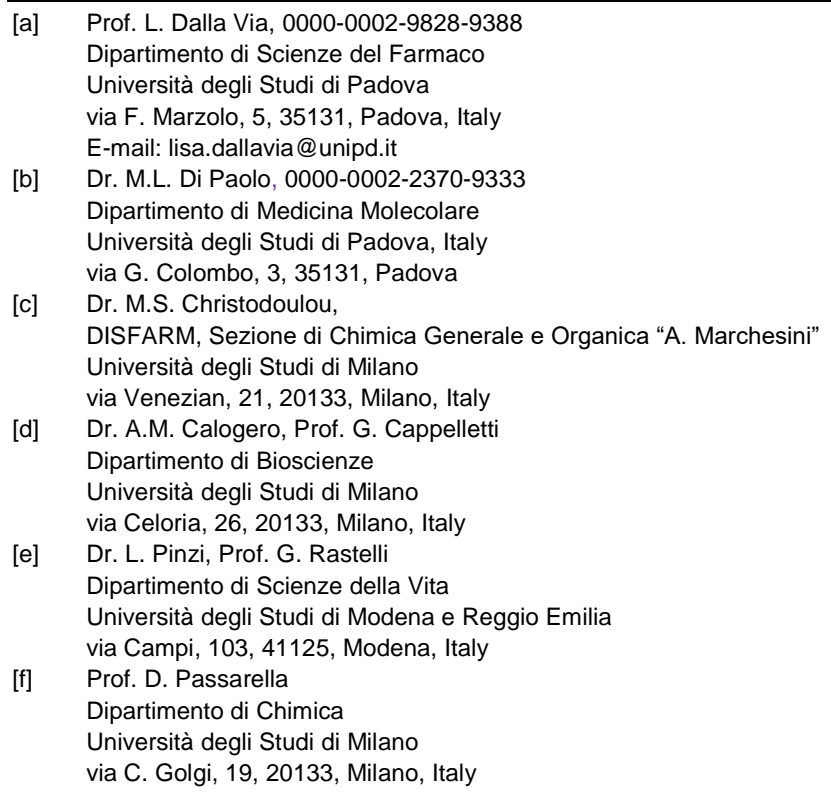

Abstract: A series of 2-phenyloxazole-4-carboxamides (4a-0) behaving as competitive inhibitors of human monoamine oxidases (MAOs) with good selectivity toward the MAO-B isoform is described. Some derivatives were also able to inhibit MAO activity in NGFdifferentiated PC12 cells, taken as a cellular model. In particular, derivative $4 a$ exerts the highest inhibitory effect without compromising cell viability. Molecular docking analysis allowed rationalizing the experimentally observed binding affinity and selectivity.

\section{Introduction}

Monoamine oxidases (MAOs, EC 1.4.3.4) are flavin adenine dinucleotide (FAD)-containing enzymes, which catalyze the oxidative deamination of neurotransmitter amines and a wide variety of amine xenobiotics, including therapeutic drugs. The two MAO-A and MAO-B isoforms (70\% of sequence identity), are bound to the outer mitochondrial membrane and expressed in different proportion in the majority of mammalian tissues, e.g., intestine, liver, placenta and brain. In human brain, MAO-A seems mainly localized at the catecholaminergic neurons while MAO-B at serotoninergic neurons and astrocytes. ${ }^{[1,2]} \mathrm{MAO}-\mathrm{A}$ preferentially metabolizes serotonin, adrenaline and noradrenaline, whereas MAO-B preferentially metabolizes phenylethylamine and benzylamine, with an overlapping metabolizing activity of both enzymes on adrenalin and dopamine..$^{[2,3]}$

Being involved in the catabolism of neurotransmitters, MAOs are established pharmacological targets in various neurological, psychiatric and neurodegenerative diseases. ${ }^{[4-6]}$ Indeed, MAO inhibitors lower the catabolism of neurotransmitters, with a concomitant decrease also in the generation of corresponding aldehydes, ammonia and hydrogen peroxide (reaction products) that, at high concentration, may be toxic and linked to a condition of oxidative stress, which is at the basis of various pathologies. MAO-A inhibitors have therapeutic utility mainly as anxiolytic and antidepressant (moclobemide and befloxatone), whereas MAO-B inhibitors are typically used for the treatment of Parkinson's disease, e.g. deprenyl as irreversible and safinamide as reversible inhibitors, ${ }^{[4]}$ as well as potential drugs in the therapy of Alzheimer's disease. ${ }^{[7]}$

Various generations of MAO inhibitors have been developed so far ${ }^{[8,9]}$ with the aim of reducing their adverse side-effects such as hypertensive crisis, liver toxicity or sleep disturbance and headache, observed with some MAO-A inhibitors. Starting more than fifty years ago with hydrazine derivatives (such as iproniazide) and then propargylamine derivatives (clorgyline, deprenyl, rasagiline), the last generation of MAO inhibitors includes a wide variety of chemotypes obtained from synthetic compounds or natural products, such as chalcones, ${ }^{[10,11]}$ pyrazoles, ${ }^{[12,13]}$ chromones, ${ }^{[14,15]}$ coumarins, ${ }^{[16,17]}$ isatin derivatives, ${ }^{[18]}$ thiazolidindiones ${ }^{[8,9,19]}$ and polyamine analogues. ${ }^{[20]}$ In particular, most recent efforts pointed to the development of reversible and MAO-B selective compound, such as safinamide $\left(K_{i} \text { of about } 500 \mathrm{nM}\right)^{[21]}$ or chlorophenyl-1-(2hydroxy-4-methoxyphenyl)penta-2,4-dien-1-one, the latter showing an $\mathrm{IC}_{50}$ of $4.51 \mathrm{nM}$. $^{[2]}$ 
Additionally, the development of dual target agents able to act both on MAO-B and other targets involved in the same pathology (such as acetylcholinesterase or butyryl-cholinesterase for Alzheimer's disease) appears very promising and, consequently, novel scaffolds endowed with two moieties for the two targets have been designed. ${ }^{[23-25]}$

A key role in the development of selective compounds was played by the resolution of the human MAO-A ${ }^{[26]}$ and MAO-B crystal structures, ${ }^{[27]}$ which may be considered a milestone in the investigation of the structural bases of substrate and inhibitor selectivity between the two isoforms. Indeed, the active site of the two isoforms consists of a hydrophobic cavity that differs in few structural details. In MAO-B, the presence of different "gating residues" conformation results in an important cavity plasticity, which may switch from a single binding pocket, when large inhibitors are bound, to a dipartite cavity when smaller ligands occupy the catalytic site in front of the FAD cofactor. ${ }^{[28]}$ This structural behaviour has important pharmacological consequences, because large inhibitors are generally highly selective towards MAO-B. Recently, large polyamine analogues that can act as substrate or inhibitors with MAO-B selectivity were described. ${ }^{[20]}$ Nevertheless, as the ideal drug candidate has not been achieved so far, researchers continued to explore this field. In the frame of a screening campaign of a huge library of natural and synthetic compounds, 2-phenyloxazole (Figure 1) was found to be a promising scaffold. The structural relationships of this scaffold with the non-selective, irreversible MAOs inhibitor isocarboxazid moved us to prepare a focused library of derivatives differently substituted at the phenyl ring and bearing an amide group at position 4 , to be evaluated as potential novel inhibitors on both hrMAO-A and hrMAO-B allowing the attainment of the kinetic parameters and the selectivity index.

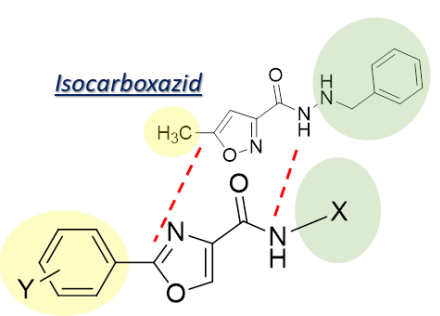

Figure 1. Structural relationships between isocarboxazid and the reported 2phenyloxazoles-4-carboxamide.

Considering the involvement of MAOs in neurons, we tested these potential MAO inhibitors taking advantage of nerve growth factor (NGF) differentiated PC12 cells, an useful cellular model system that recapitulates neuronal characteristics ${ }^{[29]}$ and that has been extensively used for investigating MAO inhibitors. ${ }^{[30]}$ Finally, docking calculations were performed to discuss structure-activity relationships (SAR) and rationalize the observed isoform selectivity of the reported MAO-B inhibitors.

\section{Results and Discussion}

\section{Chemistry}

The synthesis of the oxazole core structure of the target compound library is based on a one-pot procedure presented in the literature. ${ }^{[31,32]}$ Commercially available aldehydes 1a-c were condensed with L-serine methyl ester hydrochloride and then oxidized in situ in the presence of $\mathrm{BrCCl}_{3} / 1,8$ diazabicyclo[5.4.0]undec-7-ene (DBU) to afford the corresponding 2,4-oxazole derivatives 2. The latter ones were then cleaved in the presence of lithium hydroxide to form the corresponding acids 3 , which subsequently were coupled to the appropriate amines in the presence of 1[bis(dimethylamino)methylene]-1H-1,2,3-triazolo[4,5-b]

pyridinium 3-oxid hexafluorophosphate (HATU) to provide the desired compounds 4a-i (Scheme 1). In the case of the synthesized aldehyde 1d, ${ }^{[33]}$ this straightforward synthesis didn't furnish the desired compounds $\mathbf{4 m - 0}$. For this reason, aldehyde 1d was first protected (1e) and afterwards condensed with Lserine methyl ester hydrochloride and oxidized to provide the corresponding acid $\mathbf{3 e}$. Coupling of acid $\mathbf{3 e}$ with the appropriate amines provided the intermediate compounds $4 \mathbf{j}-\mathbf{I}$, which were subsequently deprotected in the presence of $\mathrm{BBr}_{3}$ to afford the final compounds $4 \mathrm{~m}-\mathbf{0}$ (Scheme 1).

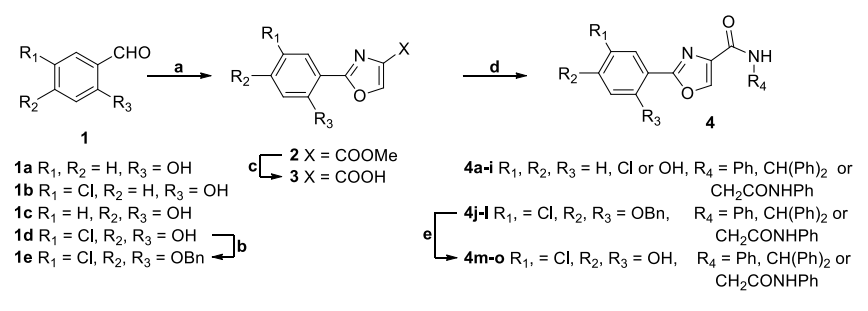

Scheme 1. Reagents and Conditions: a) i) L-serine methyl ester hydrochloride $\mathrm{MgSO}_{4}, \mathrm{Et}_{3} \mathrm{~N}$, THF, r.t. overnight, ii) $\mathrm{BrCCl}_{3}, \mathrm{DBU}$, dichloromethane (DCM), $0^{\circ} \mathrm{C}$ for $2 \mathrm{~h}$ then overnight at r.t. (15-32\%); b) $\mathrm{BnBr}, \mathrm{K}_{2} \mathrm{CO}_{3}$, acetone reflux, $4 \mathrm{~h}$; c) $\mathrm{LiOH} \cdot \mathrm{H}_{2} \mathrm{O}$, THF, $\mathrm{H}_{2} \mathrm{O}, 80^{\circ} \mathrm{C}, 3 \mathrm{~h}(91-94 \%)$; d) various amines, HATU, N,Ndiisopropylethylamine (DIPEA), DCM, reflux, $4 \mathrm{~h}$ (50-85\%); e) $\mathrm{BBr}_{3}, \mathrm{DCM}$, $78^{\circ} \mathrm{C}$ for $1 \mathrm{~h}$ then overnight at r.t. $(80-85 \%)$

\section{Inhibitory effect on hrMAO-A and hrMAO-B}

To evaluate the ability of $\mathbf{4 a - 0}$ (Table 1 ) to interact with MAOs, these compounds were tested in vitro versus both hrMAO-A and hrMAO-B. After having verified that the new 2-phenyloxazole-4carboxamides did not behave as substrates, they were assayed as potential MAO inhibitors.

All the compounds were found to act as competitive inhibitors: they decreased the affinity of the enzyme for its substrate $\left(K_{m}\right.$ increases), while $V_{\max }$ was not significantly affected, as shown in the examples of Figure 2. The Lineweaver-Burk plots in Figure 2A, showed the results obtained for the subseries $\mathbf{4 m - 4 o}$, taken like an example, along with isatin, a well-known competitive MAO inhibitor. ${ }^{[34]}$ 

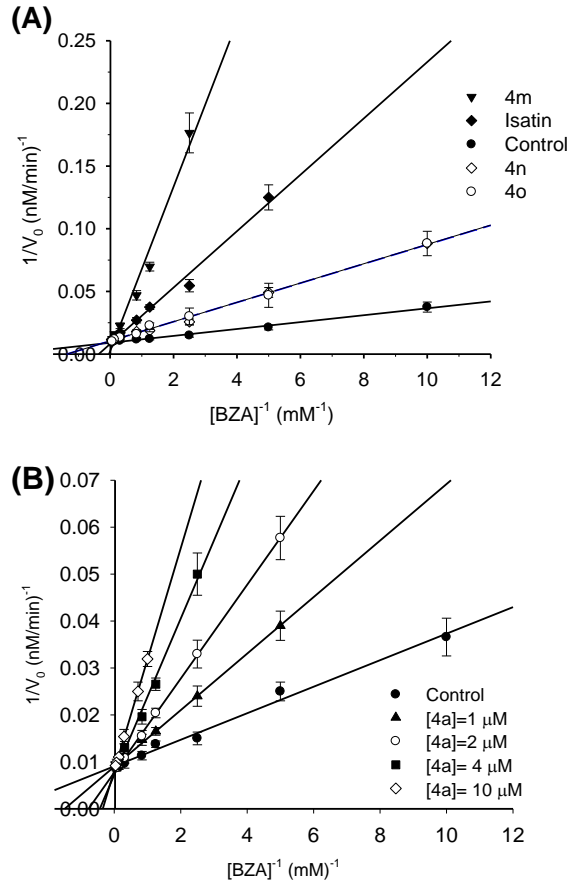

Figure 2. Competitive inhibition of hrMAO-B by 2-phenyloxazole-4carboxamides. A) Double reciprocal plots of hrMAO-B activity in the absence $(\bullet)$ and presence of $20 \mu \mathrm{M}$ isatin $(\diamond), \mathbf{4 m}(\nabla), \mathbf{4 n}(\diamond)$ and $40(\circ)$. B) Double reciprocal plots of hrMAO-B activity in the absence $(\bullet)$ and in the presence of different $4 \mathrm{a}$ concentrations $(1-10 \mu \mathrm{M})$. The $K_{i}=0.9 \pm 0.2 \mu \mathrm{M}$ for the competitive mode of inhibition of $\mathbf{4 a}$, was calculated by global fit analysis (GraphPad 5.0 software). Continuous lines are the result of linear regression analysis of plotted data $(r>0.98)$.

The double reciprocal plots (1/v vs $1 / \mathrm{S}$, Lineweaver-Burk plots) of the kinetic data of hrMAO-B in the presence of various concentrations $(1-10 \mu \mathrm{M})$ of the lead compound $4 \mathbf{a}$ (Figure $2 \mathrm{~B}$ ), clearly demonstrate the competitive mode of inhibition, being the intercept on the $y$-axis $\left(1 / \mathrm{V}_{\max }\right)$ about of the same value for all the tested concentrations. This behavior represents the classical mode of action of a competitive inhibitor, as confirmed by the global fit analysis.

The inhibition constant values $\left(\mathrm{K}_{\mathrm{i}}\right)$, which represent the dissociation constant values between the MAOs and the new derivatives, were determined for both enzymes and were reported in Table 1 along with that of isatin.

The results calculated from the kinetic analysis highlight hrMAO$B$ as the preferred isoform target of $4 a-0$ derivatives. In fact, the selectivity index ( $\mathrm{K}_{\text {iMAO-A }} / \mathrm{K}_{\text {iMAO-B }}$ ) span from about $3(\mathbf{4 f})$ to $63(\mathbf{4 a})$ (Table 1).

Inside each subseries of derivatives (4a-c, $\mathbf{4 d - f}, \mathbf{4 g}-\mathbf{i}$ and $\mathbf{4 m - 0}$ ), the most potent and selective hrMAO-B inhibitors are the compounds $\mathbf{4 a}, \mathbf{4 d}, \mathbf{4 g}$ and $\mathbf{4 m}\left(\mathrm{K}_{\mathrm{i}}\right.$ 0.6-4.3 $\mu \mathrm{M}$ for hrMAO-B; $\mathrm{K}_{\mathrm{i}}$ $\geq 28 \mu \mathrm{M}$ for hrMAO-A and selective index $\mathrm{S}$.I. $\geq 12$ ). It is of note that the introduction of bulky groups such as diphenylmethane $(\mathbf{4 b}$, $\mathbf{4 e}, \mathbf{4 h}$ and $\mathbf{4 n}$ ), or of an additional carboxamide functionality (4c, $\mathbf{4 f}, \mathbf{4 i}$ and $\mathbf{4 o}$ ) to the 4-carboxamide linker, lead to a significant decrease in hrMAO-B inhibitory capacity. In detail, an increase in $\mathrm{K}_{i}$ values from about 2 (4d-f) up to more than 20 times $(\mathbf{4 m}-\mathbf{0})$ is observed by considering the subseries. Indeed, derivative $\mathbf{4 m}$, characterized by a chlorine in $R_{1}$ and a hydroxyl substituent in both $R_{2}$ and $R_{3}$ appears as the most sensitive with respect to any structural modification at the level of the 4-carboxamide side chain.
Table 1. Inhibition constant values $\left(\mathrm{K}_{\mathrm{i}}\right)$ of $\mathbf{4 a - 0}$ for hrMAO-A and hrMAO-B Isatin was used as a reference.

\begin{tabular}{|c|c|c|c|c|c|c|}
\hline \multirow{2}{*}{ Cmp } & \multirow{2}{*}{$\mathrm{R}_{1}$} & \multirow{2}{*}{$\mathrm{R}_{2}$} & \multirow{2}{*}{$\mathrm{R}_{3}$} & \multicolumn{2}{|c|}{$\mathrm{K}_{\mathrm{i}}(\mu \mathrm{M})$} & \multirow[t]{2}{*}{ S.I. ${ }^{[a]}$} \\
\hline & & & & hrMAO-A & hrMAO-B & \\
\hline $4 a$ & $\mathrm{H}$ & $\mathrm{H}$ & $\mathrm{Ph}$ & $57 \pm 8$ & $0.9 \pm 0.2$ & 63 \\
\hline $4 b$ & $\mathrm{H}$ & $\mathrm{H}$ & $\mathrm{CH}(\mathrm{Ph})_{2}$ & $74 \pm 10$ & $5.2 \pm 0.7$ & 14 \\
\hline $4 c$ & $\mathrm{H}$ & $\mathrm{H}$ & $\mathrm{CH}_{2} \mathrm{CONHPh}$ & $90 \pm 9$ & $10.0 \pm 1.0$ & 9 \\
\hline $4 d$ & $\mathrm{Cl}$ & $\mathrm{H}$ & $\mathrm{Ph}$ & $50 \pm 7$ & $4.3 \pm 0.8$ & 12 \\
\hline $4 e$ & $\mathrm{Cl}$ & $\mathrm{H}$ & $\mathrm{CH}(\mathrm{Ph})_{2}$ & $67 \pm 7$ & $9.4 \pm 1.4$ & 7 \\
\hline $4 f$ & $\mathrm{Cl}$ & $\mathrm{H}$ & $\mathrm{CH}_{2} \mathrm{CONHPh}$ & $38 \pm 8$ & $15.0 \pm 2.0$ & 3 \\
\hline $4 \mathrm{~g}$ & $\mathrm{H}$ & $\mathrm{OH}$ & $\mathrm{Ph}$ & $28 \pm 4$ & $0.6 \pm 0.1$ & 47 \\
\hline $4 h$ & $\mathrm{H}$ & $\mathrm{OH}$ & $\mathrm{CH}(\mathrm{Ph})_{2}$ & $71 \pm 8$ & $5.0 \pm 0.8$ & 14 \\
\hline $4 i$ & $\mathrm{H}$ & $\mathrm{OH}$ & $\mathrm{CH}_{2} \mathrm{CONHPh}$ & $35 \pm 7$ & $4.2 \pm 0.3$ & 8 \\
\hline $4 m$ & $\mathrm{Cl}$ & $\mathrm{OH}$ & $\mathrm{Ph}$ & $33 \pm 4$ & $0.6 \pm 0.1$ & 55 \\
\hline $4 n$ & $\mathrm{Cl}$ & $\mathrm{OH}$ & $\mathrm{CH}(\mathrm{Ph})_{2}$ & $64 \pm 7$ & $17.1 \pm 2.1$ & 4 \\
\hline 40 & $\mathrm{Cl}$ & $\mathrm{OH}$ & $\mathrm{CH}_{2} \mathrm{CONHPh}$ & $40 \pm 5$ & $14.0 \pm 2.0$ & 3 \\
\hline Isatin $[\mathrm{b]}$ & - & - & - & $16 \pm 3$ & $4.0 \pm 1.0$ & 4 \\
\hline
\end{tabular}

[a] S.I. selectivity index $=K_{\text {ihrMAO-A }} / K_{\text {ihrMAO-B. }}$ [b] reference compound

As regards derivatives $\mathbf{4 a}, \mathbf{4 d}, \mathbf{4 g}$ and $\mathbf{4 m}$, the obtained $K_{i}$ values allowed us to draw some interesting structure-activity relationships. In particular, the replacement of the hydrogen in position $\mathrm{R}_{1}(\mathbf{4 a})$ with a chlorine $(\mathbf{4 d})$ causes a notable decrease in inhibitory activity, as indicated by an increase in $\mathrm{K}_{\mathrm{i}}$ value of about 5 times. This result suggests a detrimental role of the halogen in such position. Nevertheless, the addition of a further hydroxyl group in $\mathrm{R}_{2}(\mathbf{4 m})$ abolishes such unfavorable effect, indicating an important role, in the inhibition of the hrMAO-B activity, of the substituent in position $R_{2}$. The relevance of the hydroxyl substituents in $R_{2}$ and $R_{3}$ appears supported also by the noteworthy $\mathrm{K}_{\mathrm{i}}$ value obtained for derivative $\mathbf{4 g}$.

Finally, it is to note that the more potent and selective derivatives $(\mathbf{4 a}, \mathbf{4 g}$ and $\mathbf{4 m})$ are characterized by $K_{i}$ values of the same order of magnitude of others reversible hrMAO-B "cavity-filling" inhibitors, like safinamide, used against epilepsy[21] and pioglitazone, having $\mathrm{IC}_{50}$ values of about $0.5 \mu \mathrm{M}$. ${ }^{[35]}$

\section{Inhibitory effect on MAO-A and MAO-B activities in NGF- differentiated PC12 cells}

NGF-differentiated PC12 cells were chosen as a model of neuronal cells to evaluate the effectiveness of the new 2phenyloxazole-4-carboxamides. At first, the MAO-B activity was evaluated by using deprenyl, a well-known MAO-B irreversible inhibitor, and pargyline, irreversible dual MAO-A and -B inhibitor, as reference compounds. About $26 \%$ of monoamine oxidase activity in PC12 cell lysates was found to be inhibited by deprenyl, indicating the expression of active MAO-B, in addition to the MAO- 
A isoform, which is the one to be mainly expressed in undifferentiated PC12 cells ${ }^{[36]}$ On the basis of these results, the effect of $4 \mathrm{a}-\mathbf{0}$ was preliminarily tested at $20 \mu \mathrm{M}$ concentration, using kynuramine (kyn) as substrate $\left([\mathrm{kyn}]=10 \mu \mathrm{M}\right.$, that is $\left.[\mathrm{S}]<\mathrm{K}_{\mathrm{m}}\right)$ and isatin as reference inhibitor. The measured residual MAO activity, expressed as percentage with respect to the control, is reported in Table 2. The obtained results suggest that most derivatives are active as MAO inhibitor also in a complex matrix such as that of the NGF-differentiated PC12 cells lysates. In particular, for $\mathbf{4 a}, \mathbf{4 h}$ and $\mathbf{4 m}$ a residual MAO activity lower that $50 \%$ with respect to the control was found, allowing us to highlight them as the most interesting derivatives. Notably, for $\mathbf{4 a}$ and $\mathbf{4 m}$ a strong agreement between the inhibitory capacity on cell lysate and on hrMAO-B was found.

Table 2. Inhibitory effect of $\mathbf{4 a - 0}$ on MAO activity in NGF-differentiated PC12 cell lysate.

\begin{tabular}{|c|c|c|}
\hline Compound & $\begin{array}{l}\text { Residual MAO } \\
\text { activity at } 20 \mu \mathrm{M}\end{array}$ & $\mathrm{K}_{\mathrm{i}} \mathrm{MAOs}(\mu \mathrm{M})$ \\
\hline- & 1 & \\
\hline $4 a$ & 0.21 & $4.7 \pm 0.5$ \\
\hline $4 b$ & 0.90 & n.d..$^{[a]}$ \\
\hline 4c & 0.91 & n.d \\
\hline $4 d$ & 0.84 & n.d \\
\hline $4 e$ & 0.76 & n.d \\
\hline $4 f$ & 0.78 & n.d \\
\hline $4 g$ & 0.71 & $48.0 \pm 5.1$ \\
\hline $4 h$ & 0.29 & $10.0 \pm 2.1$ \\
\hline $4 i$ & 0.72 & n.d \\
\hline $4 m$ & 0.40 & $14.5 \pm 1.2$ \\
\hline $4 n$ & 0.70 & $45.1 \pm 5.0$ \\
\hline 40 & 0.64 & $37.8 \pm 6.4$ \\
\hline isatin $^{[b]}$ & 0.51 & $20.5 \pm 1.8$ \\
\hline
\end{tabular}

[a] n.d: not determined [b] reference compound

For the most interesting compounds, i.e. those for which a residual MAO activity lower than 0.71 was detected in PC12 cell lysates, the $K_{i}$ values were also calculated (Table 2). In detail, the obtained results indicate $\mathbf{4 a}$ as the most effective MAO inhibitor in this cellular model $\left(\mathrm{K}_{\mathrm{i}}=4.7 \mu \mathrm{M}\right)$, followed by $4 \mathrm{~h}$ and $4 \mathrm{~m}$ (10.0 and $14.5 \mu \mathrm{M}$, respectively). Conversely, $\mathbf{4 o}, \mathbf{4 n}$ and $\mathbf{4 g}$ appear to be less effective inhibitors.

Overall, these data allow us to highlight $\mathbf{4 a}$ as a very interesting lead compound that presents notable inhibitory activity both in the in vitro hr-MAOB and in the cell model. In this regard, the reduced potency of $4 \mathbf{a}$ as MAO inhibitor in cells with respect to the human recombinant enzyme $\left(\mathrm{K}_{\mathrm{i}}=0.9 \mu \mathrm{M}\right.$ vs $\left.\mathrm{K}_{\mathrm{imAOs}}=4.7 \mu \mathrm{M}\right)$ and the differences in inhibitor specificity should be due to two factors: i) $\mathrm{PC} 12$ cells contain mainly the MAO-A isoform of the enzyme on which $4 \mathrm{a}$ is significantly less effective (see Table 1, S.I.=63); ii) PC12 cells were derived from a rat pheochromocytoma and rat
MAOs can exert different sensitivity with respect to the human ones. Actually, important species-dependent differences in MAO$B$ inhibitor specificity between human and rat have been already evidenced for other classes of compounds. ${ }^{[3]}$

\section{Cell viability on HeLa and NGF-differentiated PC12 cells}

Based on the significant inhibitory effect on hr-MAO-B, the 2phenyloxazole-4-carboxamide derivatives $\mathbf{4 a}, \mathbf{4 d}, \mathbf{4 g}, \mathbf{4 h}, \mathbf{4 i}$ and $4 \mathrm{~m}$ were selected to evaluate their potential cytotoxicity, together with the less effective $\mathbf{4 n}$.

In detail, we investigate if cell viability of HeLa (human cervix adenocarcinoma) and NGF-differentiated PC12 (rat pheochromocytoma) cells is altered by treatment with these compounds at $20 \mu \mathrm{M}$ concentration, that is the experimental condition employed for the assay of residual MAO activity in cell lysate (see Table 2). The obtained data, expressed as fold change with respect to the control culture, indicate that some of them (4d, $\mathbf{4 g}, \mathbf{4 m}$ and $\mathbf{4 n}$ ) can affect significantly cell viability, and that this decrease is higher in NGF differentiated PC12 cells, which express both MAO-A and MAO-B, compared to HeLa cells, which express only MAO-A (Table 3$)^{[38]}$ In particular, $\mathbf{4 d}$ and $\mathbf{4 g}$ drastically reduce cell viability, indicating that their action compromises cell survival and induces neuronal cell death. Interestingly, the other compounds (4a, $\mathbf{4 h}$ and $\mathbf{4 i}$ ) provoke only a mild decrease in cell viability, suggesting that their effect as MAO inhibitors did not lead to cell death in this condition. Notably, derivative $\mathbf{4 a}$, the most selective toward hrMAO-B (Table 1) and the most effective as anti-MAOs in cell lysates (Table 2) shows negligible effect on cell viability.

Table 3. Effects of 4a-o on cell viability in HeLa and in NGF-differentiated PC12 cells

\begin{tabular}{lll}
\hline & \multicolumn{2}{l}{ Cell viability at $20 \mu \mathrm{M}^{[a]}$} \\
\cline { 2 - 3 } & HeLa & PC12 \\
\hline DMSO & $1.00 \pm 0.02$ & $1.00 \pm 0.05$ \\
$\mathbf{4 a}$ & $0.99 \pm 0.00$ & $0.93 \pm 0.11$ \\
$\mathbf{4 d}$ & $0.88 \pm 0.01$ & $0.60 \pm 0.03$ \\
$\mathbf{4 g}$ & $1.02 \pm 0.02$ & $0.47 \pm 0.03$ \\
$\mathbf{4 h}$ & $0.98 \pm 0.03$ & $0.85 \pm 0.09$ \\
$\mathbf{4 i}$ & $0.92 \pm 0.02$ & $0.94 \pm 0.07$ \\
$\mathbf{4 m}$ & $0.98 \pm 0.00$ & $0.77 \pm 0.12$ \\
$\mathbf{4 n}$ & $0.91 \pm 0.00$ & $0.72 \pm 0.06$ \\
\hline
\end{tabular}

[a] Data are expressed as fold change of controls (DMSO). All values are expressed as mean \pm SEM .

\section{Molecular docking studies}

Docking calculations were carried out on protein conformations whose co-crystallized ligands were on average the most similar to the compounds under investigation (Table S1). This approach has already demonstrated to help improving binding mode predictions in other studies. ${ }^{[39,40]}$ To this aim, 3D similarity analyses were carried out as described in the experimental 
section. Each co-crystallized ligand in the bound conformation was used as a query to perform the $3 \mathrm{D}$ similarity estimations. A visual inspection of the resulting alignments allowed evaluating the shape and pharmacophoric feature overlaps between the query compounds and the co-crystallized MAO ligands. The investigated compounds were found to be different from cocrystallized ligands, the Tanimoto COMBO similarity scores being below 1 for almost all compounds (Table S1). However, shape similarities (Shape Tanimoto) were significantly higher than pharmacophore similarities (Color Tanimoto), demonstrating that the compounds are similar in shape with respect to co-crystallized ligands but different in chemical structure. Similarity scores and visual inspection of the alignments allowed the identification of 2Z5X (chain A) and 2V60 (chain B) as the most suitable protein conformations for docking in MAO-A and MAO-B isoforms, respectively. Figure $\mathrm{S} 1$ of the Supporting Information shows the superimposition of $\mathbf{4 a}$ with the HRM (2Z5X) and the C17 (2V60) co-crystallized ligands as predicted by ROCS. ${ }^{[41,21]}$

Compounds were docked into the selected MAO active sites and the predicted binding modes were used to rationalize the experimentally observed binding affinity and selectivity. Figure 3 shows the binding modes of the most active compounds of the series $(\mathbf{4 a}, \mathbf{4 d}, \mathbf{4 g}$ and $\mathbf{4 m})$ in the MAO-B active site.

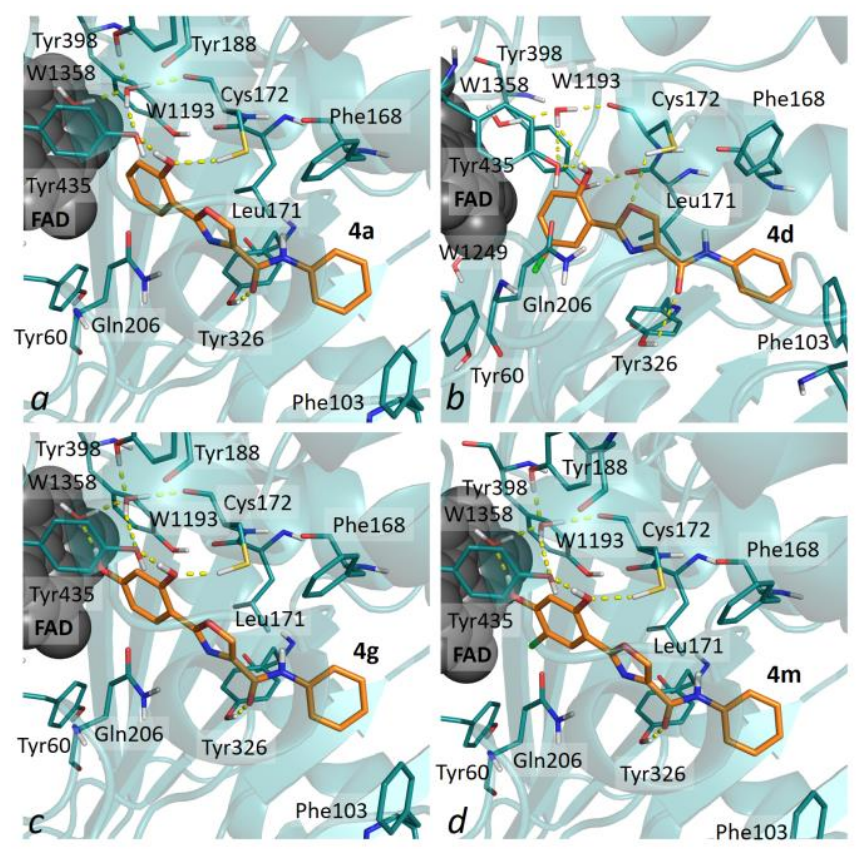

Figure 3. Predicted binding modes of the $\mathbf{4 a}$ (panel a), $\mathbf{4 d}$ (panel $b$ ), $\mathbf{4 g}$ (panel $c$ ) and $\mathbf{4 m}$ (panel $d$ ) compounds in the MAO-B active site.

All compounds were able to bind MAO-B with the phenol ring moiety oriented towards the FAD cofactor. The 2-hydroxyl group of the most active compounds formed direct hydrogen bonds with the Tyr435 and Cys172 side chains, in line with interactions previously observed for other MAO-B inhibitors. ${ }^{[8]}$ Moreover, the amide carbonyl established hydrogen bonds with the Tyr326 side chain, an interaction that is recognized to play a key role in MAO$B$ isoform selectivity. ${ }^{[8,42]}$ Interestingly, the hydroxyl groups participated to an extended network of hydrogen bonds involving conserved water molecules. In particular, the 2-hydroxyl group is engaged in an h-bond network formed by waters W1193 and
W1358, Cys172 (backbone carbonyl and side chain), Tyr435 (side chain) and Gly434 (backbone carbonyl) (Figure 3). The 4hydroxyl group, when present, participates to this h-bond network by forming direct interactions with W1358. The terminal phenyl ring binds to a distal hydrophobic pocket lined by Pro104, Leu164, Ile199 and Ile316 residues of MAO-B. Remarkably, the binding mode of these compounds is consistent with the structural alignment obtained with ROCS (Figure S2), providing evidence that structure-based and ligand-based methods converged to similar results. Moreover, the binding modes of the most active compounds significantly overlapped with the crystallographic poses of several inhibitors in complex with the MAO-B protein (Figure S3). ${ }^{[8,43]}$

Compounds with a bulkier diphenylmethane group (4b, $\mathbf{4 e}, \mathbf{4 h}$ and $\mathbf{4 n}$ ) were, on average, ten times less potent on MAO-B with respect to ligands with a terminal phenyl ring. Docking of these compounds revealed steric clashes with residues of the distal hydrophobic pocket, resulting in a $\sim 2 \AA$ shift of the amide group with respect to the phenyl substituted compounds, a loss of the Tyr326 hydrogen bond and the placement of one of the two phenyl rings in a polar cavity lined by Ser200, Thr201 and Glu84 which is normally occupied by water molecules. (Figure S4, panel a). These differences may explain the lower activity of the diphenylmethane derivatives.

Compounds with a longer N-phenylacetamide moiety (4c, 4f, 4i and $\mathbf{4 0}$ ) were, on average, ten times less active compared to the phenyl-substituted compounds. The N-phenylacetamide moiety could not be accommodated in an extended conformation because of steric clashes with the Pro104 and Leu164 residues of the distal MAO-B binding pocket. These compounds could dock only after a $180^{\circ}$ flip of the amide group and a $\sim 60^{\circ}$ tilt of the methylene linker. However, this binding mode resulted in the loss of the Tyr326 hydrogen bond and in a phenyl ring that was $~ 2 \AA$ shifted with respect to the phenyl ring of the more active compounds (Figure S4, panel b). Moreover, placement of the phenyl ring required a $1.5 \AA$ displacement of the Leu164 side chain, because of steric repulsion. These differences may explain the lower activity of the $\mathrm{N}$-phenylacetamide compounds.

According to the experimentally determined binding affinities (vide supra), selectivity indexes ranged from $3(\mathbf{4 f})$ to 63 (4a) always in favor of MAO-B (Table 1). The most active compounds of the series $(\mathbf{4 a}, \mathbf{4 g}$ and $\mathbf{4 m})$ were, on average, 50 times more potent on MAO-B rather than MAO-A. The MAO-A and MAO-B binding sites are known to differ for a few amino acids, shown in Figure S5. ${ }^{[8,42]}$ Docking into MAO-A revealed that the compounds could not bind with an orientation similar to that of MAO-B, because of significant steric clashes with the Phe208 (Ile199 in MAO-B) side chain that partially occludes the MAO-A binding site. As a result, the 2-hydroxyl group hydrogen bonds with the Asn181 (Cys172 in MAO-B) side chain, but the oxazole ring is $\sim 3 \AA$ displaced with respect to MAO-B, the hydrogen bond with Tyr326 (Ile335 in $\mathrm{MAO}-\mathrm{A}$ ) is lost, and the terminal phenyl ring binds in a position that is similar to the orientation of the additional phenyl ring of the diphenylmethane derivatives in MAO-B, interacting with Ala11, Ser209 and Val210 (Figure S6). Moreover, the phenol ring could

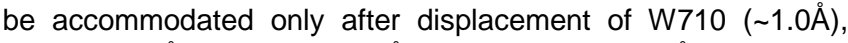

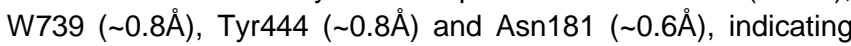
further steric constraints. The lack of a hydrogen bond with the Tyr326 residue of MAO-B in particular has been recognized to play a key role in isoform selectivity for the two enzymes. ${ }^{[8,42]}$ Overall, these differences in the predicted docking poses may 
explain the experimentally observed selectivity of the compounds for MAO-B.

\section{Investigation of the chemical novelty of the reported inhibitors}

To evaluate the novelty of the discovered compounds, maximum common substructure searches (MCSS) and 2D similarity analyses were carried out on ChEMBL as described in the methods section. Interestingly, substructure analyses indicated that derivatives of the 2-(2-hydroxyphenyl)-1,3-oxazole-4carboxamide scaffold have not been previously exploited for MAO inhibition. Moreover, 2D similarity analyses made with two different fingerprint types (MACCS and ECFP6) ${ }^{[4-46]}$ were also performed to evaluate to what extent the newly identified molecules differ from already reported MAO inhibitors. Results from these analyses revealed that the discovered compounds were on average non-similar to previously reported MAO inhibitors (Table S2) ${ }^{[47,48]}$ Indeed, visual inspection of the closest ChEMBL compounds identified through 2D similarity and MCSS analyses further demonstrated that the chemical structure of the discovered inhibitors is substantially different to that of the MAO ligands reported in ChEMBL (Table S3).

\section{Conclusions}

The preparation of a small library of new 2-phenyloxazole-4carboxamides differently substituted at the phenyl ring and bearing an amide group at position 4 (compounds 4a-0) is described. The biological evaluation highlighted for all derivatives the ability to inhibit the hr-MAO-B enzyme activity. In particular, compounds $\mathbf{4 a}, \mathbf{4 g}$ and $\mathbf{4 m}$ are low molecular weight inhibitors with $\mathrm{K}_{\mathrm{i}}$ value significantly lower than that of isatin, taken as reference. Interestingly, all derivatives were selective toward the MAO-B isoform and, in detail, a Selectivity Index ( $\mathrm{K}_{\text {iMAO-A }} / \mathrm{K}_{\text {iMAO-B }}$ ) ranging from 3 to 63 was obtained. The kinetic analysis evidenced a competitive mode of inhibition and notably, for the most interesting $\mathbf{4 a}$, the inhibitory effect was confirmed also in NGFdifferentiated PC12 cell lysates. Indeed, in this cell model, $\mathrm{K}_{\mathrm{i}}$ values of $4.7 \mu \mathrm{M}$ and $20.5 \mu \mathrm{M}$ for $4 \mathrm{a}$ and isatin, respectively, were obtained. Furthermore, the lack of any significant cytotoxicity in NGF-differentiated PC12 cells renders the MAO inhibitory effect of $4 \mathbf{a}$ on cells of particular interest. Finally, molecular modelling studies provided insights into the structural determinants responsible for the anti-MAO-B activity and selectively, and allowed us to evaluate the novelty of the newly synthetized compounds. Overall, among the reported ligands 4a may open new perspectives for the design and the development of novel effective and selective MAO-B inhibitors with potential pharmacological applications in the treatment of neurodegenerative disorders, such as Parkinson's disease.

\section{Experimental Section}

Chemistry: All reactions were carried out in oven-dried glassware and dry solvents under nitrogen atmosphere. Unless otherwise stated, all solvents were purchased from Sigma Aldrich and used without further purification. Substrates and reagents were purchased from Sigma Aldrich and used as received. Thin layer chromatography (TLC) was performed on Merck precoated $60 \mathrm{~F}_{254}$ plates. Reactions were monitored by TLC on silica gel, with detection by UV light $(254 \mathrm{~nm})$ or by a solution of ninhydrin with heating. Flash chromatography was performed using silica gel (240-400 mesh, Merck). All tested compounds possessed a purity of $>98 \%$ confirmed via elemental analyses (CHN) in a Perkin Elmer 2400 instrument. ${ }^{1} \mathrm{H}-\mathrm{NMR}$ spectra were recorded on a Bruker DRX-400 and on a Varian Oxford $300 \mathrm{MHz}$ spectrometer and are reported relative to residual $\mathrm{CDCl}_{3}$ and DMSO. ${ }^{13} \mathrm{C}-\mathrm{NMR}$ spectra were recorded on the same instrument $(100 \mathrm{MHz})$ and are reported relative to residual $\mathrm{CDCl}_{3}$ and DMSO. Chemical shifts $(\delta)$ for proton and carbon resonances are quoted in parts per million (ppm) relative to tetramethylsilane (TMS), which was used as an internal standard. MS spectra were recorded using electrospray ionization (ESI) technique on a Waters Micromass Q-Tof micro mass spectrometer.

\section{General procedure for the synthesis of esters 2}

Methyl 2-(2-hydroxyphenyl)oxazole-4-carboxylate (2a):[32] Step A: To a mixture of L-serine methyl ester hydrochloride $(0.32 \mathrm{~g}, 2.0 \mathrm{mmol})$ and $\mathrm{Mg}_{2} \mathrm{SO}_{4}(0.24 \mathrm{~g}, 2.0 \mathrm{mmol})$ in THF $(10 \mathrm{~mL})$, salicylaldehyde $(0.25 \mathrm{~g}, 2.0$ $\mathrm{mmol})$ and triethylamine $(0.56 \mathrm{~mL}, 4.0 \mathrm{mmol})$ were added and the resulting mixture was stirred overnight at room temperature. After the completion of the reaction, the mixture was filtered through celite and the filtrate was concentrated to dryness and used for the next step without any further purification.

Step B: To a cooled at $0^{\circ} \mathrm{C}$ solution of the filtrate from step A in DCM (10 $\mathrm{mL})$, bromotrichloromethane $(0.60 \mathrm{~mL}, \quad 6.0 \mathrm{mmol})$ and $1,8-$ diazabicyclo[5.4.0] undec-7-ene $(0.90 \mathrm{~mL}, 6.0 \mathrm{mmol})$ were added, and the resulting mixture was stirred for 2 hours at $0{ }^{\circ} \mathrm{C}$ and then overnight at room temperature. After the completion of the reaction, brine was added and the organic phase was extracted 3 times with DCM. The combined organic extracts were dried with $\mathrm{Na}_{2} \mathrm{SO}_{4}$, filtered and evaporated. The residue was purified by flash column chromatography (Hex/DCM 1:1) to provide compound $\mathbf{2 a}$ as a white amorphous solid (15\% yield).

Methyl 2-(5-chloro-2-hydroxyphenyl)oxazole-4-carboxylate (2b): According to the general procedure, ester $\mathbf{2} \mathbf{b}$ was obtained from aldehyde 1b after purification by flash column chromatography $(\mathrm{Hex} / \mathrm{DCM} / \mathrm{MeOH}$ 5:5:0.5) and evaporation of the solvent as a white amorphous solid (27\% yield). ${ }^{1} \mathrm{H}$ NMR (300 MHz, DMSO): $\delta=10.7$ (1H, br. s), $9.04(1 \mathrm{H}, \mathrm{s}), 7.81$ $(1 \mathrm{H}, \mathrm{d}, J 2.7 \mathrm{~Hz}), 7.48(1 \mathrm{H}, \mathrm{dd}, J 8.8 \mathrm{~Hz} J 2.7 \mathrm{~Hz}), 7.11(1 \mathrm{H}, \mathrm{d}, J 8.8 \mathrm{~Hz})$, $3.86(3 \mathrm{H}, \mathrm{s})$; ${ }^{13} \mathrm{C}$ NMR $(75 \mathrm{MHz}$, DMSO): $\delta=161.6,160.6,156.0,146.3$,

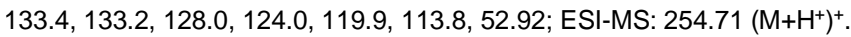
Anal. Calcd for $\mathrm{C}_{11} \mathrm{H}_{8} \mathrm{CINO}_{4}$ : C, 52.07; $\mathrm{H}, 3.18 ; \mathrm{N}, 5.52$. Found: C, 52.27; H, 3.30; N, 5.62 .

Methyl 2-(2,4-dihydroxyphenyl)oxazole-4-carboxylate (2c): According to the general procedure, ester $\mathbf{2 c}$ was obtained from aldehyde $1 \mathrm{c}$ after purification by flash column chromatography (EtOAc/DCM/MeOH 5:5:0.5) and evaporation of the solvent as a white amorphous solid (24\% yield). ${ }^{1} \mathrm{H}$ $\operatorname{NMR}(300 \mathrm{MHz}, \mathrm{DMSO}): \delta=10.6(1 \mathrm{H}$, br. s), $10.3(1 \mathrm{H}, \mathrm{br} . \mathrm{s}), 8.91(1 \mathrm{H}, \mathrm{s})$, $7.67(1 \mathrm{H}, \mathrm{d}, J 8.2 \mathrm{~Hz}), 6.48-6.45(2 \mathrm{H}, \mathrm{m}), 3.85(3 \mathrm{H}, \mathrm{s}) ; 13 \mathrm{C} \mathrm{NMR}(75$ $\mathrm{MHz}$, DMSO): $\delta=162.8,162.5,161.6,159.1,144.8,132.5,129.4,109.3$, 103.7, 103.2, 52.86; ESI-MS: $236.22\left(\mathrm{M}+\mathrm{H}^{+}\right)^{+}$. Anal. Calcd for $\mathrm{C}_{11} \mathrm{H}_{9} \mathrm{NO}_{5}$ : C, 56.16, H, 3.86; N, 5.96. Found: C, 56.27; H, 3.79; N, 5.90.

Methyl 2-(2,4-bis(benzyloxy)-5-chlorophenyl)oxazole-4-carboxylate (2e): According to the general procedure, ester $2 \mathrm{e}$ was obtained from aldehyde $1 \mathrm{e}$ after purification by flash column chromatography (Hex/DCM/EtOAc 4.5:5:0.5) and evaporation of the solvent as a white amorphous solid ( $32 \%$ yield). ${ }^{1} \mathrm{H} \mathrm{NMR}\left(400 \mathrm{MHz}, \mathrm{CDCl}_{3}\right): \delta=8.30(1 \mathrm{H}, \mathrm{s})$, $8.14(1 \mathrm{H}, \mathrm{s}), 7.50-7.35(10 \mathrm{H}, \mathrm{m}), 6.64(1 \mathrm{H}, \mathrm{s}), 5.14(4 \mathrm{H}, \mathrm{s}), 3.97(3 \mathrm{H}$, s) $;{ }^{13} \mathrm{C} \mathrm{NMR}\left(100 \mathrm{MHz}, \mathrm{CDCl}_{3}\right): \delta=162.6,161.0,157.6,153.3,144.2$, 136.8, 136.4, 134.6, 132.3, 129.4 (2C), 129.3 (2C), 129.0, 128.7, 127.7 (2C), 127.6 (2C), 116.3, 110.5, 101.3, 71.93, 71.71, 52.84; ESI-MS: 472.22 $\left(\mathrm{M}+\mathrm{H}^{+}\right)^{+}$. Anal. Calcd for $\mathrm{C}_{25} \mathrm{H}_{20} \mathrm{CINO}_{5}$ : C, $66.73 ; \mathrm{H}, 4.48 ; \mathrm{N}, 3.11$. Found: C, $66.87 ; \mathrm{H}, 4.39 ; \mathrm{N}, 3.21$. 
General procedure for the synthesis of acids 3

2-(2-hydroxyphenyl)oxazole-4-carboxylic acid (3a):[32] To a solution of ester $2 \mathrm{a}(0.20 \mathrm{~g}, 0.93 \mathrm{mmol})$ in $\mathrm{THF} / \mathrm{H}_{2} \mathrm{O}(12 / 5 \mathrm{~mL})$ lithium hydroxide monohydrate $(0.14 \mathrm{~g}, 3.2 \mathrm{mmol})$ was added and the reaction mixture was refluxed for $3 \mathrm{~h}$. Then THF was evaporated, a solution of $\mathrm{HCl} 1 \mathrm{~N}$ was added and the organic phase was extracted 3 times with EtOAc. The combined organic extracts were washed with brine dried with $\mathrm{Na}_{2} \mathrm{SO}_{4}$, filtered and evaporated to provide compound $\mathbf{3} \mathbf{a}$ as a white amorphous solid (92\% yield).

2-(5-chloro-2-hydroxyphenyl)oxazole-4-carboxylic acid (3b): According to the general procedure, acid $\mathbf{3 b}$ was obtained from ester $\mathbf{2} \mathbf{b}$ after evaporation of the solvent as a white amorphous solid $(91 \%$ yield). ${ }^{1} \mathrm{H}$ NMR $(300 \mathrm{MHz}, \mathrm{DMSO}): \delta=13.3(1 \mathrm{H}, \mathrm{br} . \mathrm{s}), 10.8(1 \mathrm{H}, \mathrm{br} . \mathrm{s}), 8.92(1 \mathrm{H}$, s), $7.78(1 \mathrm{H}, \mathrm{d}, J 2.8 \mathrm{~Hz}), 7.45(1 \mathrm{H}, \mathrm{dd}, J 8.9 \mathrm{~Hz} J 2.8 \mathrm{~Hz}), 7.09(1 \mathrm{H}, \mathrm{d}, J$ $8.9 \mathrm{~Hz}) ;{ }^{13} \mathrm{C}$ NMR $(75 \mathrm{MHz}, \mathrm{DMSO}): \delta=161.9,160.0,155.6,145.3,133.9$, 133.0, 127.1, 123.6, 119.5, 113.1; ESI-MS: $262.63(\mathrm{M}+\mathrm{Na})^{+}$. Anal. Calcd for $\mathrm{C}_{10} \mathrm{H}_{6} \mathrm{CINO}_{4}: \mathrm{C}, 50.11 ; \mathrm{H}, 2.53 ; \mathrm{N}, 5.85$. Found: $\mathrm{C}, 50.31 ; \mathrm{H}, 2.44 ; \mathrm{N}$, 5.75 .

2-(2,4-dihydroxyphenyl)oxazole-4-carboxylic acid (3c): According to the general procedure, acid 3c was obtained from ester 2c after evaporation of the solvent as a brown amorphous solid (92\% yield). ${ }^{1} \mathrm{H}$ $\operatorname{NMR}(300 \mathrm{MHz}, \mathrm{DMSO}): \delta=13.2(1 \mathrm{H}$, br. s) $, 10.7(1 \mathrm{H}, \mathrm{br} . \mathrm{s}), 10.2(1 \mathrm{H}, \mathrm{br}$ s), $8.81(1 \mathrm{H}, \mathrm{s}), 7.66(1 \mathrm{H}, \mathrm{d}, J 8.5 \mathrm{~Hz}), 6.48-6.44(2 \mathrm{H}, \mathrm{m}) ;{ }^{13} \mathrm{C}$ NMR $(75$ $\mathrm{MHz}, \mathrm{DMSO}): \delta=162.4,162.0,158.7,144.9,133.0,128.6,115.8,108.9$, 103.3, 102.9; ESI-MS: $244.18(\mathrm{M}+\mathrm{Na})^{+}$. Anal. Calcd for $\mathrm{C}_{10} \mathrm{H}_{7} \mathrm{NO}_{5}: \mathrm{C}$ 54.29; H, 3.19; N, 6.34. Found: C, 54.19; H, 3.10; N, 6.42

2-(2,4-bis(benzyloxy)-5-chlorophenyl)oxazole-4-carboxylic acid (3e): According to the general procedure, acid $3 e$ was obtained from ester $2 e$ after evaporation of the solvent as a brown amorphous solid (94\% yield). ${ }^{1} \mathrm{H}$ NMR $(400 \mathrm{MHz}, \mathrm{DMSO}): \delta=13.0(1 \mathrm{H}$, br. s), $8.83(1 \mathrm{H}, \mathrm{s}), 7.89(1 \mathrm{H}, \mathrm{s})$ $7.59-7.33(10 \mathrm{H}, \mathrm{m}), 7.22(1 \mathrm{H}, \mathrm{s}), 5.35(2 \mathrm{H}, \mathrm{s}), 5.34(2 \mathrm{H}, \mathrm{s}) ;{ }^{13} \mathrm{C}$ NMR (100 MHz, DMSO): $\delta=162.6,159.4,157.0$ (2C), 137.0, 136.5, 134.5, 130.7, 129.1 (4C), 128.9, 128.7, 128.2 (4C), 127.6, 114.1, 109.7, 101.8, 71.08, 70.93; ESI-MS: $458.53(\mathrm{M}+\mathrm{Na})^{+}$. Anal. Calcd for $\mathrm{C}_{24} \mathrm{H}_{18} \mathrm{CINO}_{5}: \mathrm{C}$, 66.12; H, 4.16; N, 3.21. Found: C, 66.31; H, 4.20; N, 3.19

\section{General procedure for the synthesis of amides 4}

2-(2-hydroxyphenyl)- $\mathrm{N}$-phenyloxazole-4-carboxamide (4a):[32] To a solution of acid $3 a(0.067 \mathrm{~g}, 0.33 \mathrm{mmol})$ in DCM $(10 \mathrm{~mL})$, HATU $(0.18 \mathrm{~g}$, $0.46 \mathrm{mmol})$ and DIPEA $(0.093 \mathrm{~mL}, 0.52 \mathrm{mmol})$ were added and the reaction was stirred for $30 \mathrm{~min}$ at r.t. Then, aniline $(0.033 \mathrm{~mL}, 0.36 \mathrm{mmol})$ was added and the new solution was refluxed for $4 \mathrm{~h}$. After the completion of the reaction, sat. $\mathrm{NH}_{4} \mathrm{Cl}$ was added and the organic phase was extracted 3 times with DCM. The combined organic extracts were washed with $\mathrm{H}_{2} \mathrm{O}$ and Brine, dried with $\mathrm{Na}_{2} \mathrm{SO}_{4}$, filtered and evaporated. The residue was purified by flash column chromatography (Hex/EtOAc 7:3) to provide amide $4 \mathbf{a}$ as a white amorphous solid (85\% yield). Anal. Calcd for $\mathrm{C}_{16} \mathrm{H}_{12} \mathrm{~N}_{2} \mathrm{O}_{3}$ : C, 68.56; $\mathrm{H}, 4.32 ; \mathrm{N}, 9.99$. Found: $\mathrm{C}, 68.73 ; \mathrm{H}, 4.39 ; \mathrm{N}, 9.91$.

N-benzhydryl-2-(2-hydroxyphenyl)oxazole-4-carboxamide (4b): :32] $^{[3}$ According to the general procedure, amide $\mathbf{4 b}$ was obtained from acid $\mathbf{3 a}$ and benzhydrylamine after purification by flash column chromatography (Hex/EtOAc 7:3) and evaporation of the solvent as a white amorphous solid (80\% yield). Anal. Calcd for $\mathrm{C}_{23} \mathrm{H}_{18} \mathrm{~N}_{2} \mathrm{O}_{3}$ : $\mathrm{C}, 74.58 ; \mathrm{H}, 4.90 ; \mathrm{N}, 7.56$. Found: C, 74.79; $\mathrm{H}, 4.98 ; \mathrm{N}, 7.48$.

\section{2-(2-hydroxyphenyl)-N-(2-oxo-2-(phenylamino)ethyl)oxazole-4-} carboxamide (4c): ${ }^{[31]}$ According to the general procedure, amide $4 \mathrm{c}$ was obtained from acid $\mathbf{3 a}$ and 2 -Amino- $N$-phenylacetamide after purification by flash column chromatography (Hex/EtOAc 4:6) and evaporation of the solvent as a white amorphous solid (75\% yield). Anal. Calcd for $\mathrm{C}_{18} \mathrm{H}_{15} \mathrm{~N}_{3} \mathrm{O}_{4}$ : C, 64.09; $\mathrm{H}, 4.48 ; \mathrm{N}, 12.46$. Found: $\mathrm{C}, 64.34 ; \mathrm{H}, 4.55 ; \mathrm{N}$, 12.31 .
2-(5-chloro-2-hydroxyphenyl)-N-phenyloxazole-4-carboxamide (4d) According to the general procedure, amide $\mathbf{4 d}$ was obtained from acid $\mathbf{3 b}$ and aniline after purification by flash column chromatography (Hex/EtOAc 8:2) and evaporation of the solvent as a white amorphous solid ( $70 \%$ yield). ${ }^{1} \mathrm{H}$ NMR (300 MHz, DMSO): $\delta=10.5(1 \mathrm{H}, \mathrm{s}), 8.89(1 \mathrm{H}, \mathrm{s}), 7.82-7.77(3 \mathrm{H}$, $\mathrm{m}), 7.37(2 \mathrm{H}, \mathrm{t}, J 8.1 \mathrm{~Hz}), 7.24(1 \mathrm{H}, \mathrm{d}, J 4.2 \mathrm{~Hz}), 7.13(1 \mathrm{H}, \mathrm{t}, J 7.8 \mathrm{~Hz})$ $7.00(1 \mathrm{H}, \mathrm{d}, J 8.7 \mathrm{~Hz}) ;{ }^{13} \mathrm{C} \mathrm{NMR}(75 \mathrm{MHz}, \mathrm{DMSO}): \delta=159.2,158.1,155.8$, $142.5,139.1,137.2,129.5(2 \mathrm{C}), 129.0,127.7,124.9,122.8,121.6(2 \mathrm{C})$, 121.5, 113.9; ESI-MS: $337.25(\mathrm{M}+\mathrm{Na})^{+}$. Anal. Calcd for $\mathrm{C}_{16} \mathrm{H}_{11} \mathrm{CIN}_{2} \mathrm{O}_{3}: \mathrm{C}$, 61.06; H, 3.52; N, 8.90. Found: C, 61.29; H, 3.57; N, 3.47.

N-benzhydryl-2-(5-chloro-2-hydroxyphenyl)oxazole-4-carboxamide (4e): According to the general procedure, amide $4 \mathrm{e}$ was obtained from acid 3b and benzhydrylamine after purification by flash column chromatography (Hex/EtOAc 7:3) and evaporation of the solvent as a white amorphous solid (65\% yield). ${ }^{1} \mathrm{H}$ NMR (400 MHz, DMSO): $\delta=10.5$ $(1 \mathrm{H}$, br. s), $9.62(1 \mathrm{H}, \mathrm{d}, J 8.8 \mathrm{~Hz}), 8.84(1 \mathrm{H}, \mathrm{s}), 7.84(1 \mathrm{H}, \mathrm{d}, J 2.4 \mathrm{~Hz}), 7.48$ $(1 \mathrm{H}, \mathrm{dd}, J 8.8 \mathrm{~Hz} J 2.4 \mathrm{~Hz}), 7.40-7.28(10 \mathrm{H}, \mathrm{m}), 7.11(1 \mathrm{H}, \mathrm{d}, J 8.8 \mathrm{~Hz})$, $6.45(1 \mathrm{H}, \mathrm{d}, J 8.8 \mathrm{~Hz}) ;{ }^{13} \mathrm{C}$ NMR $(100 \mathrm{MHz}, \mathrm{DMSO}): \delta=160.0,159.8,156.0$, 143.5, 143.2 (2C), 137.1, 133.7, 129.5 (4C), 128.9 (4C), 128.3 (2C), 127.3, 124.4, 120.6, 113.4, 56.56; ESI-MS: $427.00(\mathrm{M}+\mathrm{Na})^{+}$. Anal. Calcd for $\mathrm{C}_{23} \mathrm{H}_{17} \mathrm{ClN}_{2} \mathrm{O}_{3}$ : C, 68.24; $\mathrm{H}, 4.23 ; \mathrm{N}, 6.92$. Found: $\mathrm{C}, 68.40 ; \mathrm{H}, 4.31 ; \mathrm{N}$, 6.81 .

\section{2-(5-chloro-2-hydroxyphenyl)-N-(2-oxo-2-}

(phenylamino)ethyl)oxazole-4-carboxamide (4f): According to the general procedure, amide $\mathbf{4 f}$ was obtained from acid $\mathbf{3 b}$ and 2-Amino- $\mathrm{N}$ phenylacetamide after purification by flash column chromatography (DCM/MeOH 95:5) and evaporation of the solvent as a white amorphous solid $\left(60 \%\right.$ yield). ${ }^{1} \mathrm{H}$ NMR $(400 \mathrm{MHz}, \mathrm{DMSO}): \delta=10.5(1 \mathrm{H}, \mathrm{s}), 10.1(1 \mathrm{H}$, s), $9.12(1 \mathrm{H}, \mathrm{t}, J 6.0 \mathrm{~Hz}), 8.82(1 \mathrm{H}, \mathrm{s}), 7.86(1 \mathrm{H}, \mathrm{d}, J 2.8 \mathrm{~Hz}), 7.61(2 \mathrm{H}, \mathrm{d}$, J $7.6 \mathrm{~Hz}), 7.50(1 \mathrm{H}, \mathrm{dd}, J 9.2 \mathrm{~Hz} J 2.8 \mathrm{~Hz}), 7.32(2 \mathrm{H}, \mathrm{t}, J 7.6 \mathrm{~Hz}), 7.14(1 \mathrm{H}$, d, J $9.2 \mathrm{~Hz}), 7.04(1 \mathrm{H}, \mathrm{t}, J 7.6 \mathrm{~Hz}), 4.09(2 \mathrm{H}, \mathrm{d}, J 6.0 \mathrm{~Hz}) ;{ }^{13} \mathrm{C} \mathrm{NMR}$ (100MHz, DMSO): $\delta=167.9,160.4,159.5,157.6$ (from HMBC), 151.5 (from HMBC), 142.3 (from HSQC), 139.4, 136.5, 132.9, 129.2 (3C), 127.0, 123.7, 119.6 (2C), 113.0, 42.95; ESI-MS: $394.06(\mathrm{M}+\mathrm{Na})^{+}$. Anal. Calcd for $\mathrm{C}_{18} \mathrm{H}_{14} \mathrm{CIN}_{3} \mathrm{O}_{4}$ : C, 58.15; H, 3.80; N, 11.30. Found: C, 58.31; H, 3.89; N, 11.20 .

\section{2-(2,4-dihydroxyphenyl)-N-phenyloxazole-4-carboxamide}

(4g): According to the general procedure, amide $\mathbf{4 g}$ was obtained from acid $\mathbf{3 c}$ and aniline after purification by flash column chromatography (DCM/MeOH 98:2) and evaporation of the solvent as a white amorphous solid $(60 \%$ yield). ${ }^{1} \mathrm{H}$ NMR (300 MHz, DMSO): $\delta=10.35$ (1H, br. s), $10.32(1 \mathrm{H}$, br. s), $10.2(1 \mathrm{H}$, br. s), $8.77(1 \mathrm{H}, \mathrm{s}), 7.76(2 \mathrm{H}, \mathrm{d}, J 7.5 \mathrm{~Hz}), 7.67(1 \mathrm{H}, \mathrm{d}, J 8.7 \mathrm{~Hz})$, $7.36(2 \mathrm{H}, \mathrm{t}, J 7.5 \mathrm{~Hz}), 7.12(1 \mathrm{H}, \mathrm{t}, J 7.5 \mathrm{~Hz}), 6.46(1 \mathrm{H}, \mathrm{dd}, J 8.7 \mathrm{~Hz} J 2.4$ $\mathrm{Hz}), 6.42(1 \mathrm{H}, \mathrm{d}, J 2.4 \mathrm{~Hz}) ;{ }^{13} \mathrm{C}$ NMR $(75 \mathrm{MHz}, \mathrm{DMSO}): \delta=162.4,161.0$, 158.6, 158.5, 141.8, 138.6, 136.2, 129.0 (2C), 128.6, 124.6, 121.4 (2C), 108.9, 103.5, 102.9; ESI-MS: $318.95(\mathrm{M}+\mathrm{Na})^{+}$. Anal. Calcd for $\mathrm{C}_{16} \mathrm{H}_{12} \mathrm{~N}_{2} \mathrm{O}_{4}$ : C, 64.86; H, 4.08; N, 9.46. Found: C, 65.04; H, 4.12; N, 9.39.

N-benzhydryl-2-(2,4-dihydroxyphenyl)oxazole-4-carboxamide (4h) According to the general procedure, amide $\mathbf{4 h}$ was obtained from acid $3 \mathrm{c}$ and benzhydrylamine after purification by flash column chromatography (DCM/MeOH 98:2) and evaporation of the solvent as a white amorphous solid (60\% yield). ${ }^{1} \mathrm{H}$ NMR (300 MHz, DMSO): $\delta=10.4$ ( $1 \mathrm{H}$, br. s), 10.2 $(1 \mathrm{H}$, br. s), $9.54(1 \mathrm{H}, \mathrm{d}, J 9.0 \mathrm{~Hz}), 8.67(1 \mathrm{H}, \mathrm{s}), 7.66(1 \mathrm{H}, \mathrm{d}, J 8.6 \mathrm{~Hz}), 7.37$ $-7.27(10 \mathrm{H}, \mathrm{m}), 6.48-6.41(3 \mathrm{H}, \mathrm{m}) ;{ }^{13} \mathrm{C} \mathrm{NMR}(75 \mathrm{MHz}, \mathrm{DMSO}): \delta=162.7$, 161.3, 159.9, 158.8, 142.6 (2C), 141.6, 136.3, 129.7, 129.2 (4C), 128.6 (4C), 128.1, 128.0, 109.3, 103.9, 103.3, 56.24; ESI-MS: $409.17(\mathrm{M}+\mathrm{Na})^{+}$. Anal. Calcd for $\mathrm{C}_{23} \mathrm{H}_{18} \mathrm{~N}_{2} \mathrm{O}_{4}$ : C, 71.49; $\mathrm{H}, 4.70 ; \mathrm{N}, 7.25$. Found: C, 71.73; $\mathrm{H}, 4.79 ; \mathrm{N}, 7.17$.

2-(2,4-dihydroxyphenyl)-N-(2-oxo-2-(phenylamino)ethyl)oxazole-4carboxamide (4i): According to the general procedure, amide $4 \mathbf{i}$ was obtained from acid $3 \mathrm{c}$ and 2 -Amino- $N$-phenylacetamide after purification by flash column chromatography $\mathrm{DCM} / \mathrm{MeOH}$ 9:1) and evaporation of the solvent as a white amorphous solid (50\% yield). ${ }^{1} \mathrm{H} \mathrm{NMR}(400 \mathrm{MHz}$, DMSO): $\delta=10.8(1 \mathrm{H}$, br. s), $10.1(1 \mathrm{H}$, br. s), $9.20(1 \mathrm{H}, \mathrm{t}, J 6.0 \mathrm{~Hz}), 8.84$ 
$(1 \mathrm{H}, \mathrm{s}), 8.01(1 \mathrm{H}, \mathrm{d}, J 8.8 \mathrm{~Hz}), 7.61(2 \mathrm{H}, \mathrm{d}, J 8.0 \mathrm{~Hz}), 7.32(2 \mathrm{H}, \mathrm{t}, J 8.0 \mathrm{~Hz})$ $7.12(1 \mathrm{H}, \mathrm{d}, J 2.4 \mathrm{~Hz}), 7.06(1 \mathrm{H}, \mathrm{t}, J 7.6 \mathrm{~Hz}), 6.98(1 \mathrm{H}, \mathrm{dd}, J 8.8 \mathrm{~Hz} J 2.4$ $\mathrm{Hz}), 4.10(2 \mathrm{H}, \mathrm{d}, J 6.0 \mathrm{~Hz}){ }^{13} \mathrm{C} \mathrm{NMR}(100 \mathrm{MHz}, \mathrm{DMSO}): \delta=168.5,160.8$, 160.1, 159.2, 156.5, 142.1 (from HSQC), 140.0, 136.9, 130.4, 129.9 (2C), 124.4, 120.2 (2C), 110.4, 110.0, 107.5, 43.54; ESI-MS: $376.35(\mathrm{M}+\mathrm{Na})^{+}$. Anal. Calcd for $\mathrm{C}_{18} \mathrm{H}_{15} \mathrm{~N}_{3} \mathrm{O}_{5}$ : C, 61.19; H, 4.28; N, 11.89. Found: C, 61.33; $\mathrm{H}, 4.34 ; \mathrm{N}, 11.80$.

\section{2-(2,4-bis(benzyloxy)-5-chlorophenyl)-N-phenyloxazole-4-}

carboxamide (4j): According to the general procedure, amide $4 \mathbf{j}$ was obtained from acid $\mathbf{3 e}$ and aniline after purification by flash column chromatography (Hex/EtOAc 8:2) and evaporation of the solvent as a white amorphous solid ( $70 \%$ yield). ${ }^{1} \mathrm{H}$ NMR $(300 \mathrm{MHz}$, DMSO): $\delta=9.99$ (1H, br. s), $8.08(1 \mathrm{H}, \mathrm{s}), 8.01(1 \mathrm{H}, \mathrm{s}), 7.78(2 \mathrm{H}, \mathrm{d}, J 7.5 \mathrm{~Hz}), 7.54-7.31$ $(12 \mathrm{H}, \mathrm{m}), 7.12(1 \mathrm{H}, \mathrm{t}, J 7.5 \mathrm{~Hz}), 6.59(1 \mathrm{H}, \mathrm{s}), 5.37(2 \mathrm{H}, \mathrm{s}), 5.34(2 \mathrm{H}, \mathrm{s}) ;{ }^{13} \mathrm{C}$ NMR $(75 \mathrm{MHz}$, DMSO): $\delta=162.1,160.3,157.9,157.4,143.5,137.3,137.1$ 136.8, 136.6, 130.1, 129.5 (4C), 129.0 (2C), 128.6 (2C), $128.5(4 \mathrm{C}), 128.0$, 121.6 (2C), 115.4, 110.0, 101.7, 71.55, 71.43; ESI-MS: $533.71(\mathrm{M}+\mathrm{Na})^{+}$. Anal. Calcd for $\mathrm{C}_{30} \mathrm{H}_{23} \mathrm{CIN}_{2} \mathrm{O}_{4}$ : C, 70.52; $\mathrm{H}, 4.54 ; \mathrm{N}, 5.48$. Found: C, 70.77 $\mathrm{H}, 4.60 ; \mathrm{N}, 5.46$.

\section{N-benzhydryl-2-(2,4-bis(benzyloxy)-5-chlorophenyl)oxazole-4-}

carboxamide (4k): According to the general procedure, amide $\mathbf{4 k}$ was obtained from acid $\mathbf{3 e}$ and benzhydrylamine after purification by flash column chromatography (Hex/EtOAc 8:2) and evaporation of the solvent as a white amorphous solid $\left(70 \%\right.$ yield). ${ }^{1} \mathrm{H} \mathrm{NMR}\left(400 \mathrm{MHz}, \mathrm{CDCl}_{3}\right): \delta=$ $8.27(1 \mathrm{H}, \mathrm{s}), 8.02(1 \mathrm{H}, \mathrm{s}), 7.62(1 \mathrm{H}, \mathrm{d}, J 8.8 \mathrm{~Hz}), 7.46-7.26(20 \mathrm{H}, \mathrm{m})$ $6.68(1 \mathrm{H}, \mathrm{s}), 6.48(1 \mathrm{H}, \mathrm{d}, J 8.8 \mathrm{~Hz}), 5.20(2 \mathrm{H}, \mathrm{s}), 5.12(2 \mathrm{H}, \mathrm{s}) ;{ }^{13} \mathrm{C}$ NMR $\left(100 \mathrm{MHz}, \mathrm{CDCl}_{3}\right): \delta=160.6,159.8,157.5,157.2,141.9(2 \mathrm{C}), 141.6,137.4$ $136.6,136.3,132.0,129.4(8 \mathrm{C}), 129.3(2 \mathrm{C}), 129.0,128.8,128.3(4 \mathrm{C})$, 128.2 (2C), $127.7,127.6,116.2,110.7,101.5,72.04,71.75,57.04$; ESIMS: $624.38(\mathrm{M}+\mathrm{Na})^{+}$. Anal. Calcd for $\mathrm{C}_{37} \mathrm{H}_{29} \mathrm{ClN}_{2} \mathrm{O}_{4}$ : C, 73.93; $\mathrm{H}, 4.86 ; \mathrm{N}$, 4.66. Found: C, $74.22 ; \mathrm{H}, 4.94 ; \mathrm{N}, 4.60$

\section{2-(2,4-bis(benzyloxy)-5-chlorophenyl)-N-(2-oxo-2-}

(phenylamino)ethyl)oxazole-4-carboxamide (4I): According to the general procedure, amide $4 \mathrm{I}$ was obtained from acid $3 \mathrm{e}$ and 2 -Amino- $N$ phenylacetamide after purification by flash column chromatography (Hex/EtOAc 4:6) and evaporation of the solvent as a white amorphous solid ( $50 \%$ yield). ${ }^{1} \mathrm{H} \mathrm{NMR}\left(400 \mathrm{MHz}, \mathrm{CDCl}_{3}\right): \delta=8.54(1 \mathrm{H}, \mathrm{br} . \mathrm{s}), 8.27(1 \mathrm{H}$, s), $8.04(1 \mathrm{H}, \mathrm{s}), 7.69(1 \mathrm{H}, \mathrm{t}, J 6.0 \mathrm{~Hz}), 7.56(2 \mathrm{H}, \mathrm{d}, J 8.0 \mathrm{~Hz}), 7.49-7.31$ $(12 \mathrm{H}, \mathrm{m}), 7.12(1 \mathrm{H}, \mathrm{t}, J 7.6 \mathrm{~Hz}), 6.67(1 \mathrm{H}, \mathrm{s}), 5.18(2 \mathrm{H}, \mathrm{s}), 5.16(2 \mathrm{H}, \mathrm{s})$, $4.26(2 \mathrm{H}, \mathrm{d}, J 6.0 \mathrm{~Hz}) ;{ }^{13} \mathrm{C} \mathrm{NMR}\left(100 \mathrm{MHz}, \mathrm{CDCl}_{3}\right): \delta=166.9,162.0,159.2$, 157.0, 156.7, 140.7 (HSQC), 137.6, 136.1, 136.0, 135.6, 131.1, 129.0 (2C) $128.8(2 \mathrm{C}), 128.7(2 \mathrm{C}), 128.4,128.3,127.1(4 \mathrm{C}), 124.4,120.2(2 \mathrm{C}), 115.8$, 109.8, 100.9, 71.51, 71.08, 44.57; MS: $591.05(\mathrm{M}+\mathrm{Na})^{+}$. Anal. Calcd for $\mathrm{C}_{32} \mathrm{H}_{26} \mathrm{ClN}_{3} \mathrm{O}_{5}: \mathrm{C}, 67.66 ; \mathrm{H}, 4.61 ; \mathrm{N}, 7.40$. Found: $\mathrm{C}, 67.88 ; \mathrm{H}, 4.68 ; \mathrm{N}$, 7.34.

\section{General procedure for the deprotection of amides $4 \mathrm{j}-\mathrm{I}$}

2-(5-chloro-2,4-dihydroxyphenyl)-N-phenyloxazole-4-carboxamide (4m): To a cold at $-78^{\circ} \mathrm{C}$ solution of amide $4 \mathrm{j}(0.060 \mathrm{~g}, 0.12 \mathrm{mmol})$ in DCM (8.3 mL), BBr $1.0 \mathrm{M}$ in $\mathrm{DCM}(0.26 \mathrm{~mL}, 0.26 \mathrm{mmol}, 1.1$ equiv per bond) was added dropwise and the reaction was kept for another $1 \mathrm{~h}$ at the same temperature and then overnight at r.t. Then, the solution was cooled at $0{ }^{\circ} \mathrm{C}$, neutralized with $\mathrm{MeOH}$ and $\mathrm{HCl} 1 \mathrm{~N}$ was added. The organic phase was extracted twice with DCM. The combined organic extracts were washed with water and brine, dried with $\mathrm{Na}_{2} \mathrm{SO}_{4}$, filtered and evaporated. The residue was purified by flash column chromatography (Hex/EtOAc $7: 3$ ) to provide analogue $4 \mathrm{~m}$ as a white amorphous solid $\left(85 \%\right.$ yield). ${ }^{1} \mathrm{H}$ NMR $(400 \mathrm{MHz}, \mathrm{DMSO}): \delta=11.0(1 \mathrm{H}, \mathrm{br} . \mathrm{s}), 10.4(1 \mathrm{H}, \mathrm{br} . \mathrm{s}), 10.3(1 \mathrm{H}, \mathrm{br}$. s), $8.81(1 \mathrm{H}, \mathrm{s}), 7.79(1 \mathrm{H}, \mathrm{s}), 7.78(2 \mathrm{H}, \mathrm{d}, J 8.8 \mathrm{~Hz}), 7.38(2 \mathrm{H}, \mathrm{t}, J 7.6 \mathrm{~Hz})$, $7.14(1 \mathrm{H}, \mathrm{t}, J 7.6 \mathrm{~Hz}), 6.67(1 \mathrm{H}, \mathrm{s}) ;{ }^{13} \mathrm{C}$ NMR $(100 \mathrm{MHz}, \mathrm{DMSO}): \delta=160.5$, 159.3, 158.1, 157.5, 143.0, 139.2, 137.1, 129.8 (2C), 128.9, 125.3, 122.0 (2C), 112.9, 105.5, 104.7; ESI-MS: $353.75(\mathrm{M}+\mathrm{Na})^{+}$. Anal. Calcd for $\mathrm{C}_{16} \mathrm{H}_{11} \mathrm{ClN}_{2} \mathrm{O}_{4}$ : C, 58.11; H, 3.35; N, 8.47. Found: C, 58.36; H, 3.40; N, 8.41 .
N-benzhydryl-2-(5-chloro-2,4-dihydroxyphenyl)oxazole-4-

carboxamide (4n): According to the general procedure, amide $4 \mathrm{n}$ was obtained from amide $\mathbf{4 k}$ after purification by flash column chromatography (Hex/EtOAc 6:4) and evaporation of the solvent as a white amorphous solid (85\% yield). ${ }^{1} \mathrm{H}$ NMR $(400 \mathrm{MHz}, \mathrm{DMSO}): \delta=11.0(1 \mathrm{H}, \mathrm{br} . \mathrm{s}), 10.4$ $(1 \mathrm{H}$, br. s), $9.55(1 \mathrm{H}, \mathrm{d}, J 8.8 \mathrm{~Hz}), 8.72(1 \mathrm{H}, \mathrm{s}), 7.75(1 \mathrm{H}, \mathrm{s}), 7.40-7.28$ $(10 \mathrm{H}, \mathrm{m}), 6.63(1 \mathrm{H}, \mathrm{s}), 6.45(1 \mathrm{H}, \mathrm{d}, J 8.8 \mathrm{~Hz}) ;{ }^{13} \mathrm{C} \mathrm{NMR}(100 \mathrm{MHz}, \mathrm{DMSO})$ : $\delta=160.4,160.1,158.0,157.4,142.9(3 \mathrm{C}), 136.8,129.5(4 \mathrm{C}), 128.9(4 \mathrm{C})$, 128.6, 128.3 (2C), 112.8, 105.5, 104.8, 56.52; ESI-MS: $443.87(\mathrm{M}+\mathrm{Na})^{+}$. Anal. Calcd for $\mathrm{C}_{23} \mathrm{H}_{17} \mathrm{CIN}_{2} \mathrm{O}_{4}$ : C, 65.64; $\mathrm{H}, 4.07 ; \mathrm{N}, 6.66$. Found: $\mathrm{C}, 65.89$; $\mathrm{H}, 4.14 ; \mathrm{N}, 6.59$.

\section{2-(5-chloro-2,4-dihydroxyphenyl)-N-(2-oxo-2-}

(phenylamino)ethyl)oxazole-4-carboxamide (40): According to the general procedure, amide 40 was obtained from amide $4 \mathrm{l}$ after purification by flash column chromatography (Hex/EtOAc 4:6) and evaporation of the solvent as a white amorphous solid (80\% yield). ${ }^{1} \mathrm{H}$ NMR $(400 \mathrm{MHz}$, DMSO): $\delta=11.0(1 \mathrm{H}$, br. s), $10.4(1 \mathrm{H}$, br. s), $10.1(1 \mathrm{H}$, br. s), $9.07(1 \mathrm{H}, \mathrm{t}$, $J 6.0 \mathrm{~Hz}), 8.70(1 \mathrm{H}, \mathrm{s}), 7.77(1 \mathrm{H}, \mathrm{s}), 7.60(2 \mathrm{H}, \mathrm{d}, J 8.0 \mathrm{~Hz}), 7.32(2 \mathrm{H}, \mathrm{t}, J$ $8.0 \mathrm{~Hz}), 7.06(1 \mathrm{H}, \mathrm{t}, J 7.2 \mathrm{~Hz}), 6.66(1 \mathrm{H}, \mathrm{s}), 4.07(2 \mathrm{H}, \mathrm{d}, J 6.0 \mathrm{~Hz}) ;{ }^{13} \mathrm{C}$ NMR $(100 \mathrm{MHz}, \mathrm{DMSO}): \delta=168.7,161.0,160.1,158.0,157.5,141.6$ (HSQC), 140.0, 136.8, 129.9 (2C), 128.7, 124.4, 120.2 (2C), 112.8, 105.4, 104.8, 30.11; ESI-MS: $410.80(\mathrm{M}+\mathrm{Na})^{+}$. Anal. Calcd for $\mathrm{C}_{18} \mathrm{H}_{14} \mathrm{CIN}_{3} \mathrm{O}_{5}: \mathrm{C}$, 55.75; H, 3.64; N, 10.84. Found: C, 55.97; H, 3.70; N, 10.77 .

\section{Biological evaluation}

Monoamine oxidase activity assays: Human recombinant MAO A and MAO B (hrMAO-A and hrMAO-B, respectively) expressed in baculovirus infected BT1 cells $(5 \mathrm{mg} / \mathrm{mL})$ and horseradish peroxidase were purchased from Fluka-Sigma-Aldrich s.r.l. (Italy). Monoamine oxidase activity was determined by two different methods: I) by detecting the $\mathrm{H}_{2} \mathrm{O}_{2}$ generation rate by the peroxidase-coupled continuous assay that uses the Amplex Red reagent, as fluorigenic substrate for the peroxidase, ${ }^{[49]}$ ii) by using kyn as substrate and measuring the formation of 4-hydroxyquinoline as reaction product of MAO activity.[50] The kyn assay was used both to verify with a different method the inhibition by the various compounds with human MAOs and for the assays of monoamine oxidase activity in PC12 cells lysates.

All MAOs activity assays were carried out in Hepes $50 \mathrm{mM}, \mathrm{KCl} 50 \mathrm{mM}$, $\mathrm{NaCl} 120 \mathrm{mM}, \mathrm{pH} 7.4$ and at $37^{\circ} \mathrm{C}$, as previously reported.[20]

The assays monitoring the $\mathrm{H}_{2} \mathrm{O}_{2}$ production rate were carried out in a final volume of $800 \mu \mathrm{l}$, in the presence of Amplex Red $(100 \mu \mathrm{M})$ and horseradish peroxidase type II (5 $\left.\mathrm{UmL}^{-1}\right)$, and using $p$-tyramine ( $p$-Tyr) (0.1-1.4 mM) and benzylamine (BZA) (0.1-15 mM) as MAO-A and MAO-B substrate, respectively. Initial velocities were determined by measuring the increase in fluorescence intensity $\left(\lambda_{\text {exc }}=563 \mathrm{~nm}\right.$ and $\left.\lambda_{\text {em }}=586 \mathrm{~nm}\right) ; \mathrm{H}_{2} \mathrm{O}_{2}$ generation rate was calculated from the change in fluorescence intensity, by means of calibration curves obtained by serial dilution of stock solution of $\mathrm{H}_{2} \mathrm{O}_{2}$, in the presence of the various substrate concentration and of compounds 4 in absence of MAO enzyme.

MAO activity assay with the kyn method was carried out as previously described, with minor modifications. ${ }^{[50]}$ Briefly: enzyme stock solutions were diluted with assay buffer to get a final concentration $0.006 \mathrm{mg} / \mathrm{mL}$ for hrMAO-A, $0.04 \mathrm{mg} / \mathrm{mL}$ for hrMAO-B, or $0.4 \mathrm{mg} / \mathrm{mL}$ for PC12 lysates (in $200 \mu \mathrm{L}$ ), in the presence or absence of the various inhibitors. After 5 min of pre-incubation with the compounds, the substrate (kyn) was added at a final concentration of $10 \mu \mathrm{M}$ (first-order conditions, [kyn] $<K_{m k y n}$, being $\mathrm{K}_{\mathrm{mkyn}}=139 \pm 39$ and $112 \pm 25 \mu \mathrm{M}$ for hrMAO-A and hrMAO-B, respectively and $K_{m k y n}=40 \pm 10$ for MAOs in PC12 lysates). After 45 min incubation at $37^{\circ} \mathrm{C}$, the reaction was stopped by addition of $2 \mathrm{M} \mathrm{NaOH}(80 \mu \mathrm{L})$ and 480 $\mu \mathrm{L}$ of distilled water. Kyn deaminated by MAOs spontaneously cyclises to give 4-hydroxyquinoline, the amount of which was determined by the fluorescence intensity of the peak of its emission spectra $\left(\lambda_{\mathrm{exc}}=330 \mathrm{~nm}\right.$ and $\lambda_{\mathrm{em}} 330-530 \mathrm{~nm}$ ), using a specific calibration curve built with the standard 4-hydroxyquinoline. 
The relative amounts of MAO-B activity expressed in lysates from PC12 cells was evaluated by measuring amine oxidase activity, after 15 minutes of pre-incubation with deprenyl $(2 \mu \mathrm{M})$, irreversible and selective MAO-B inhibitors, before adding the substrate $(\mathrm{kyn}=300 \mu \mathrm{M}$, saturating substrate concentration). A control sample, pre-incubated in the absence of inhibitor, was taken as reference control and a sample pre-incubated with pargyline $(125 \mu \mathrm{M})$ irreversible MAO inhibitor was taken as reference sample of fully inhibited MAO activity. A sample without enzyme was always run and taken as "blank sample". A relative amount of about $26 \%$ of MAO-B activity was found in PC12 cell lysates (74\% of residual MAO activity after deprenyl pre-incubation).

The following stock solutions were used: compounds 4 and isatin (reference competitive MAO inhibitor) $(20 \mathrm{mM})$ in DMSO; the standard irreversible MAOs inhibitors deprenyl and pargyline $(10 \mathrm{mM})$ in water.

The protein content of samples was measured by the Bradford method, with bovine serum albumin as standard. ${ }^{[51]}$

A Cary-Eclipse fluorimeter (Varian Inc., Palo Alto, CA, USA) and a Cary 50 Scan UV-visible were used for fluorimetric and spectrophotometric measurements, respectively.

MAO inhibition kinetic parameters: Steady-state kinetic parameters ( $V_{\max }$ and $K_{m}$ ) were calculated by fitting the Michaelis-Menten equation to the experimental data (initial rate of reactions $\left(\mathrm{V}_{0}\right)$ vs substrate concentrations) by non-linear regression analysis, with Sigma Plot software, version 9.0 (Jandel Scientific, San Rafael, CA, USA) and the value of the kinetic parameter obtained from the best fit and its S.E.M. are reported.

The apparent $V_{\max }$ and $K_{m}$ values of hrMAO-A and hrMAO-B were determined in the presence of the different concentrations of the various compounds. The mode of inhibition was determined by global fit analysis (GraphPad 5.0 software) of the initial rate of reaction $\left(\mathrm{V}_{0}\right)$ vs substrate concentration plots, in the presence and absence of inhibitor, to fit equations for competitive, mixed, non-competitive and uncompetitive inhibition models; the fit giving the highest $r^{2}$ value was selected for the calculation of inhibition constants $\left(K_{i}\right)$. The results are presented as double reciprocal Lineweaver-Burk plots $(1 / v$ vs $1 / \mathrm{S})$ to show the competitive mode of inhibition of the tested compounds.

Inhibitory activity of compounds on MAO in PC12 cell lysates was evaluated by using a fixed concentration $(20 \mu \mathrm{M})$ of each compound; results are presented as residual MAO activity with respect to control sample. $K_{i}$ values for MAOs in PC12 lysates were determined for some of the more effective compounds.

Unless stated otherwise, the correlation coefficient for linear regression was 0.98 or greater.

All experiments were performed at least in triplicate, and the experimental data were expressed as the mean \pm standard deviation (SD).

Cell cultures, extraction and treatments: HeLa (human cervix adenocarcinoma) cells were grown in DMEM (ECM0101L, Euroclone) supplemented with 10\% Fetal Bovine Serum (ECS0180LI, Euroclone), 2 $\mathrm{mM}$ L-Glutamine (ECB3000D, Euroclone), $200 \mu \mathrm{g} / \mathrm{mL}$ Penicillin/Streptomycin (ECB3001D, Euroclone). PC12 (rat pheochromocytoma) cells were routinely maintained in RPMI 1640 medium (ECB9006L, Euroclone) supplemented with 10\% Horse Serum (ECS0090D, Euroclone), 5\% Fetal Clone Serum (HyClone, SH30066.02, ThermoFisher), $2 \mathrm{mM}$ L-Glutamine, $200 \mu \mathrm{g} / \mathrm{mL}$ Penicillin/Streptomycin. To induce neuronal differentiation in PC12 cells, $50 \mathrm{ng} / \mathrm{mL}$ of human $\beta$-Nerve Growth Factor (NGF, 450-01, PeproTech Inc.) were added to the lowserum differentiation medium (RPMI 1640 supplemented with 1\% Horse serum, $200 \mu \mathrm{g} / \mathrm{mL}$ Penicillin/Streptomycin, $2 \mathrm{mM} \mathrm{L-glutammine).} \mathrm{PC12}$ cells were plated at a density of 120.000 cells/well in a 12 multiwell plate previously coated with poli-L-Lysine (P4707, SIGMA-Aldrich) Differentiation medium has been replaced every two days. Cells were incubated at $37^{\circ} \mathrm{C}$, in a humidified atmosphere, $5 \% \mathrm{CO}_{2}$.

To obtain cellular extracts of PC12 cells for the monoamine oxidase activity assay, after eight days in differentiation medium, NGF-differentiated cells were gently washed twice with PBS and lysed with $20 \mathrm{mM}$ Hepes, $\mathrm{pH} 7.4$, in presence of Protease Inhibitors (M250, AMRESCO). Cellular extracts were immediately frozen in liquid nitrogen and stored at $-80^{\circ} \mathrm{C}$.

To evaluate compound effects on living cells, HeLa and NGF-differentiated PC12 cells were plated into 12-well cell culture plates at a density of 210,000 cells/well and 120,000 cells/well respectively. Compounds were tested on HeLa cells the day after seeding or in NGF-differentiated PC12 cells at 8DIV. Before treatments, both HeLa and PC12 culture media were replaced with fresh media and compounds were added to obtain a final concentration of $20 \mu \mathrm{M}$. Stock solutions of compounds were made in dimethylsulfoxide (DMSO), used as control. Treated cells were incubated for additional 48 hours at $37^{\circ} \mathrm{C}$, and then MTT (3-(4,5-dimethylthiazol)-2,5 diphenyltetrazolium bromide, M2128, SIGMA-Aldrich) assay was performed to test cell viability. The intensity of the solution is measures at a wavelength of $570 \mathrm{~nm}$ using a plate reader spectrophotometer (Infinite 200Pro, Tecan).

\section{Molecular Modeling}

Proteins and co-crystallized ligands preparation: Crystal structures of human Monoamine Oxidase A (MAO-A) and Monoamine Oxidase B (MAO-B) proteins were first downloaded from the Protein Data Bank (accessed on January $24^{\text {th }}, 2018$ ), resulting in 4 and 40 crystal structures for MAO-A and MAO-B, respectively. Structures were subsequently split into their chains, leading to two datasets of 6 (MAO-A) and 88 (MAO-B) distinct structures (Table S4). ${ }^{[52]}$ Afterwards, the structures were aligned and prepared for the subsequent calculations by using the Protein Structure Alignment and Protein Preparation Wizard utilities available within Maestro 10.3 of the Schrödinger suite (release 2014-3) respectively. ${ }^{[53-58]}$ Missing amino acid side chains and hydrogen atoms were first added and mismatches in the atom types and bond connectivity were fixed. Then, ligand-protein geometries were optimized through a restrained minimization, employing a $0.3 \AA$ root mean square threshold. Finally, co-crystallized ions and organic solvent molecules were removed from the prepared complexes. Flavin-adenine dinucleotide (FAD) cofactor and congeners were considered as part of the MAO structures during the docking calculations. ${ }^{[59]}$

Ligand similarity and protein conformation selection: Docking calculations were performed on representative crystal structures whose ligands were on average the most similar to the newly identified inhibitors. The 3D similarity estimations were performed as follows. Co-crystallized ligands were first extracted from the prepared crystal structures in their bound conformation, leading to two datasets of 6 and 79 ligands of MAO$A$ and MAO-B, respectively. Then, the extracted ligands were used as reference queries for the $3 \mathrm{D}$ similarity estimations. The MAO inhibitors identified in this work were first prepared by using the LigPrep (version 3.5 utility available within the Schrödinger suite (release 2014-3). ${ }^{[53,59]}$ lonization states and tautomers potentially present at physiological $\mathrm{pH}$ were assigned and ligand structures were minimized. Afterwards, a conformational sampling was performed for each ligand with the OMEGA2 software (version 2.5.1.4). ${ }^{[60,61]}$ Up to 400 conformers per compound were generated for the ligands, using defaults parameters.

Ligand similarity was performed by using the ROCS software (version 3.2.1.4).[62,63] Twenty random starting positions were set for the initial ligand alignment to better assess the ligand similarity. The Tanimoto COMBO score, which takes into account shape (ShapeTanimoto) and chemical pattern (ColorTanimoto) similarities, was used to quantify $3 \mathrm{D}$ ligand similarity (Table S1). A final step of visual inspection of the ligand 
alignments led to the selection of two active site conformations to be used for docking, i.e. $2 \mathrm{Z} 5 \mathrm{X}$ chain $\mathrm{A}$ for MAO-A, and $2 \mathrm{~V} 60$ chain $\mathrm{B}$ for MAOB. $[41,21]$

Docking calculations: Docking calculations were performed on the active site of the prepared protein structures by using the Glide (version 6.8) docking program. ${ }^{64,65]}$ All water molecules were removed from the selected active sites, except for W1193, W1249 and W1358 in MAO-B and W710, W725 and W739 in MAO-A crystal structures (residue numbering refers to $2 \mathrm{~V} 60$ for MAO-B and 2Z5X for MAO-A). These water molecules are highly conserved across mono-amino oxidase crystal structure complexes. Active sites grids (outer box of $10 \AA \times 10 \AA \times 10 \AA$ ) were centered on the centroids of the bound ligands and generated using defaults settings. The docking protocol was first validated by redocking the HRM and C17 ligands co-crystallized in the 2Z5X and 2V60 crystal structures, respectively. ${ }^{[41,21]}$ Then, docking calculations were performed and the resulting docking poses were visually inspected.

Control calculations: To evaluate the novelty of the discovered MAO inhibitors with respect to previously reported ligands, 2D similarity analyses between the reported compounds and ligands taken from the ChEMBL database (release 23 , accessed on April $3^{\text {th }}, 2018$ ) were performed. ${ }^{[66,67]}$ Only annotations with a ChEMBL assay confidence score equal or greater than 8 were considered. MACCS and ECFP6 fingerprints available within the OpenEye OEGraphSim Python Toolkits were used for the similarity calculations. ${ }^{[68,69,47,48]}$ The chemical structures of the newly identified MAO inhibitors were used as reference queries for the similarity evaluations. A total of 2 (2D fingerprint types MACCS and ECFP6) $\times 12$ (compounds) $=24$ ranks were obtained. Ligand similarity was evaluated in terms of the Tanimoto similarity score. Table S2 reports the averaged similarities of the newly identified compounds with respect to the already known MAO-A and MAO-B inhibitors extracted from the ChEMBL database.

\section{Acknowledgements}

M.L.D.P and L.D.V. are grateful for the financial support provided from DOR (University of Padova). The authors would also like to thank Dr, Paola Vanzani for her technical assistance.

Keywords: competitive inhibitors $\cdot$ cytotoxicity $\cdot$ molecular modeling $\cdot$ monoamine oxidases $\cdot 2$-phenyloxazole-4carboxamide derivatives

\section{References:}

[1] K. N. Westlund, R. M. Denney, L. M. Kochersperger, R. M. Rose, C. W. Abell, Science 1985, 230, 181.

[2] M. B. Youdim, D. E. Edmondson, K. F. Tipton, Nat. Rev. Neurosci. 2006 , 7, 295.

[3] K. F. Tipton, J. Neural. Transm. (Vienna). 2018, 125, 1519.

[4] Z. Fišar, Prog. Neuropsychopharmacol. Biol. Psychiatry 2016, 69, 112.

[5] J. P. M. Finberg, Pharmacol. Therap. 2014, 143, 133.

[6] M. Bortolato, G. Floris, J. C Shih, J. Neural. Transm. (Vienna) 2018, 125, 1589.

[7] J. H. Park, Y. H. Ju, J. W. Choi, H. J. Song, B.K. Jang, J. Woo, H. Chun, H. J. Kim, S. J. Shin, O. Yarishkin, S. Jo, M. Park, S. K. Yeon, S. Kim, J. Kim, M. H. Nam, A. M. Londhe, J. Kim, S. J. Cho, S. Cho, C. Lee, S. Y Hwang, S. W. Kim, S. J. Oh, J. Cho, A. N. Pae, C. J. Lee, K. D. Park, Sci. Adv. 2019, 5:eaav0316.

[8] A.C. Tripathi, S. Upadhyay, S. Paliwal, S.K. Saraf, Eur. J. Med. Chem. 2018, 145, 445.

[9] S. Carradori, D. Secci, J. P. Petzer, Expert. Opin. Ther. Pat. 2018, 3, 211
[10] B. Mathew, A. Haridas, J. Suresh, G. E. Mathew, G. Uçar, V. Jayaprakash, Cent. Nerv. Syst. Agents Med. Chem. 2016, 16, 120

[11] J. Suresh, S. C. Baek, S. P. Ramakrishnan, H. Kim, B. Mathew Int. J. Biol. Macromol. 2018, 108, 660 .

[12] D. Secci, S. Carradori, A. Bolasco, B. Bizzarri, M. D'Ascenzio, E. Maccioni, Curr. Top. Med. Chem. 2012,12, 2240.

[13] B. Evranos-Aksoz, G. Uçar, K. Yelekci, Comb. Chem. High Throughput Screen. 2017, 20, 510 .

[14] B. Mathew, G. E. Mathew, J. P. Petzer, A. Petzer, Comb. Chem. High Throughput Screen. 2017, 20, 522

[15] J. Reis, F. Cagide, M. E. Valencia, J. Teixeira, D. Bagetta, C. Pérez, E. Uriarte, P. J. Oliveira, F. Ortuso, S. Alcaro, M. I. Rodríguez-Franco, F. Borges, Eur. J. Med. Chem., 2018, 158, 781.

[16] S. Rauhamäki, P. A. Postila, S. Niinivehmas, S. Kortet, E. Schildt, M Pasanen, E. Manivannan, M. Ahinko, P. Koskimies, N. Nyberg, P. Huuskonen, E. Multamäki, M. Pasanen R. O. Juvonen, H. Raunio, J. Huuskonen, O. T. Pentikäinen, Front. Chem. 2018, 6, 41.

[17] A. Fonseca, J. Reis, T. Silva, M. J. Matos, D. Bagetta, F. Ortuso, S. Alcaro, E. Uriarte, F. Borges, J. Med. Chem. 2017, 60, 7206

[18] R. K. Tripathi, S. Krishnamurthy, S. R. Ayyannan, ChemMedChem 2016, 11,119

[19] S. Carradori, R. Silvestri, J. Med. Chem. 2015, 58, 6717

[20] E. Bonaiuto, A. Milelli, G. Cozza, V. Tumiatti, C. Marchetti, E. Agostinelli, C. Fimognari, P. Hrelia, A. Minarini, M. L. Di Paolo, Eur. J. Med. Chem. 2013, 70, 88 .

[21] C. Binda, J. Wang, L. Pisani, C. Caccia, A. Carotti, P. Salvati, D. E Edmondson, A. Mattevi, J. Med. Chem. 2007, 50, 5848.

[22] N. Desideri, R. Fioravanti, L. Proietti Monaco, M. Biava, M. Yáñez, F. Ortuso, S. Alcaro, Eur. J. Med. Chem. 2013, 59, 91.

[23] J. Joubert, G. B. Foka. B. P. Repsold, D. W. Oliver, E. Kapp, S. F. Malan, Eur. J. Med. Chem. 2017, 125, 853

[24] R. K. P. Tripathi, M. Sasi V, S.K. Gupta, S. Krishnamurthy, S. R. Ayyannan, J. Enzyme Inhib. Med. Chem. 2018, 33, 37

[25] D. Secci, S. Carradori, A. Petzer, P. Guglielmi, M. D'Ascenzio, P Chimenti, D. Bagetta, S. Alcaro, G. Zengin, J. P. Petzer, F. Ortuso, Enzyme Inhib. Med. Chem. 2019, 34, 597.

[26] L. De Colibus, M. Li, C. Binda, A. Lustig, D. E. Edmondson, A. Mattevi, Proc. Natl. Acad. Sci. U S A. 2005, 102, 12684.

[27] C. Binda, P. Newton-Vinson, F. Hubálek, D. E. Edmondson, A. Mattevi, Nat. Struct. Biol. 2002, 9, 22

[28] D. E. Edmondson, C. Binda, J. Wang, A. K. Upadhyay, A Mattevi, Biochemistry 2009, 48, 4220

[29] L. A. Greene, A. S. Tischler, Proc. Natl. Acad. Sci. 1976, 73, 2424.

[30] D. S. Goldstein, Y. Jinsmaa, P. Sullivan, C. Holmes, I. J. Kopin, Y Sharabi, J. Pharmacol. Exp. Ther. 2016, 356, 483.

[31] T. H. Graham, Org. Lett. 2010, 12, 3614.

[32] Y. Li, P. M. Woster, Med. Chem. Comm. 2015, 6, 613.

[33] M. Lee, N. G. Gubernator, D. Sulzer, D. Sames, J. Am. Chem. Soc. 2010 132, 8828.

[34] F. Hubalek, C. Binda, A. Khalil, M. Li, A. Mattevi, N. Castagnoli, D. E. Edmondson, J. Biol. Chem. 2005, 280, 15761.

[35] C. Binda, M. Aldeco, W.J. Geldenhuys, M. Tortorici, A. Mattevi, D. E. Edmondson, ACS Med. Chem. Lett. 2011, 3, 39.

[36] S. Abu-Raya, E. Blaugrund, V. Trembovler, E. Shilderman-Bloch, E. Shohami, P. Lazarovici, J. Neurosci. Res. 1999, 58, 456.

[37] L. Novaroli, A. Daina, E. Favre, J. Bravo, A. Carotti, F. Leonetti, M. Catto, P. A. Carrupt, M. Reist, J. Med. Chem. 2006, 49, 6264.

[38] X. Wu, L. Li, W. Shi, Q. Gong, X. Li, H. Ma, Anal. Chem. 2016, 88, 1440

[39] X. Xu, C. Yan, X. Zou, J. Comput. Aided Mol. Des. 2017, 31, 689

[40] F. Broccatelli, N. Brown, J. Chem. Inf. Mod. 2014, 54, 1634.

[41] S. Y. Son, J. Ma, Y. Kondou, M. Yoshimura, E. Yamashita, T. Tsukihara, Proc. Nat. Acad. Sci. U.S.A. 2008, 105, 5739

[42] E. M. Milczek, C. Binda, S. Rovida, A. Mattevi, D. E. Edmondson, FEBS J. 2011, 278, 4860 .

[43] F. Chimenti, A. Bolasco, D. Secci, P. Chimenti, A. Granese, S. Carradori, M. Yanez, F. Orallo, F. Ortuso, S. Alcaro, Bioorg. Med. Chem. 2010, 18, 5715

[44] J. L. Durant, B. A. Leland, D. R. Henry, J. G. Nourse, J. Chem. Inf Comput. Scie. 2002, 42, 1273.

[45] D. Rogers, M. Hahn, J. Chem. Inf. Model. 2010, 50, 742. 
[46] H. Briem, U. F. Lessel, Perspect. Drug Discov. Design 2000, 20, 231.

[47] S. W. Muchmore, D. A. Debe, J. T. Metz, S. P. Brown, Y. C. Martin, P. J. Hajduk, J. Chem. Inf. Model. 2008, 48, 941.

[48] S. Jasial, Y. Hu, M. Vogt, J. Bajorath, F1000Research. 2016, 5(Chem. Inf. Sci.), 591.

[49] M. Zhou, N. Panchuk-Voloshina, Anal. Biochem. 1997, 253, 169.

[50] M. F. Santillo, Y. Liu, M. Ferguson, S. N. Vohra, P. L. Wiesenfeld, Toxicol. Vitro 2014, 28, 403.

[51] M. M. Bradford, Anal. Biochem. 1976, 72, 248-254

[52] H. M. Berman, J. Westbrook, Z. Feng, G. Gilliland, T. N. Bhat, H. Weissig, I. N. Shindyalov, P. E. Bourne, Nucleic Acids Res. 2000, 28, 235-242.

[53] Schrödinger Release 2014-3: Maestro, Schrödinger, LLC, New York, NY, (USA) 2014

[54] G. Madhavi Sastry, M. Adzhigirey, T. Day, R. Annabhimoju, W. Sherman, J. Comput. Aided Mol. Des. 2013, 27, 221.

[55] Schrödinger Release 2014-3: Schrödinger, L. Prime. New York, NY (USA) 2014

[56] M. P. Jacobson, D. L. Pincus, C. S. Rapp, T. J. F. Day, B. Honig, D. E. Shaw, R. A. Friesner, Proteins 2004, 55, 351.

[57] Schrödinger Release 2014-3: Impact, Schrödinger, L. New York, NY (USA) 2014

[58] J. L. Banks, H. S. Beard, Y. Cao, A. E. Cho, W. Damm, R. Farid, A. K. Felts, T. A. Halgren, D. T. Mainz, J. R. Maple, R. Murphy, D. M. Philipp, M. P. Repasky, L. Y. Zhang, B. J. Berne, R. A: Friesner, E. Gallicchio, R. M. Levy, J. Comput. Chem. 2005, 26, 1752.

[59] Schrödinger Release 2014-3: LigPrep, Schrödinger, L. New York, NY (USA) 2014.

[60] OMEGA 2.5.1.4: OpenEye Scientific Software, Santa Fe, NM.

[61] P. C. Hawkins, A. G. Skillman, G. L. Warren, B. A. Ellingson, M. T. Sthal, J. Chem. Inf. Model 2010, 50, 572.

[62] ROCS 3.2.1.4: OpenEye Scientific Software, Santa Fe, NM (USA).

[63] P. C. D. Hawkins, A. G. Skillman, A. Nicholls, J. Med. Chem. 2007, 50, 74.

[64] R. A. Friesner, J. L. Banks, R. B. Murphy, T. A. Halgren, J. J. Klicic, D. T. Mainz, M. P. Repasky, E. H. Knoll, M. Shelley, J. K.Perry, D. E. Shaw, P. Francis, P. S. Shenkin, J. Med. Chem. 2004, 47, 1739.

[65] Schrödinger Release 2014-3: Glide (Version 6.3), Schrödinger, LLC, New York, NY (USA) 2017

[66] A. Gaulton, L. J. Bellis, A. P. Bento, J. Chambers, M. Davies, A. Hersey, Y. Light, S. McGlinchey, D. Michalovich, B. Al-Lazikani, J. P. Overington, Nucleic Acids Res. 2012, 40, D1100-D1107.

[67] A. P. Bento, A. Gaulton, A. Hersey, L. J. Bellis, J. Chambers, M. Davies, F. A. Krüger, Y. Light, L. Mak, S. McGlinchey, M. Nowotka, G. Papadatos, R. Santos, J. P. Overington, Nucleic Acids Res. 2014, 42, D1083-D1090.

[68] OpenEye Python Toolkits, Jun. 1, OpenEye Scientific Software, Santa Fe, NM (USA) 2017.

[69] GraphSim Toolkit, Jun. 1, OpenEye Scientific Software, Santa Fe, NM (USA) 2017. http://www.eyesopen.com. 


\section{Table of Contents}

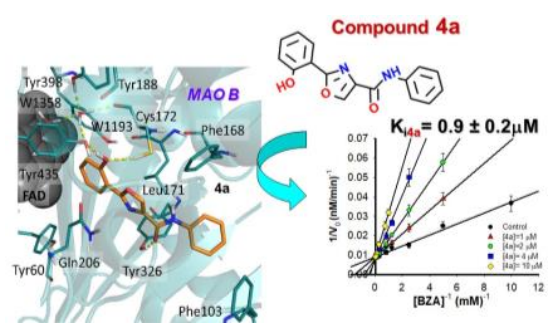

Most simple and most effective. The inhibitory behaviour on MAOs activity of new 2-phenyloxazole-4-carboxamide derivatives was assayed. Compound $\mathbf{4 a}$ emerged as a potent and selective competitive inhibitor of hrMAO-B. The significant inhibitory effect on MAO activity in NGF-differentiated PC12 cells along with the absence of cytotoxicity render 4 a a promising new scaffold in drug discovery for neurodegenerative diseases. 